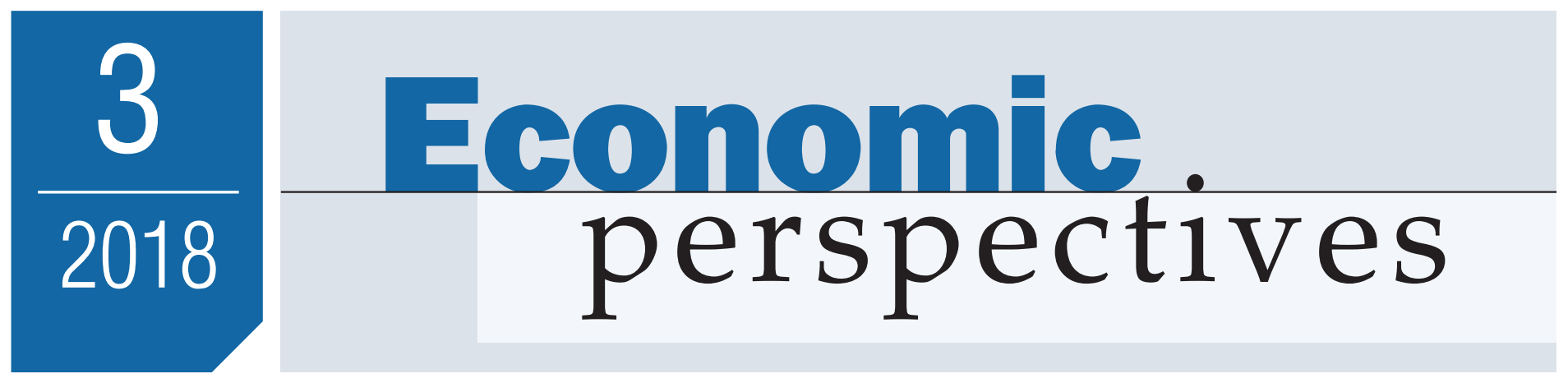

https://doi.org/10.21033/ep-2018-3

\title{
Seasonal and business cycles of U.S. employment
}

\section{Menelik Geremew and François Gourio}

\section{Introduction and summary}

The U.S. economy alternates between periods of expansion, when employment and production grow, and periods of recession, when they fall. This pattern is called the business cycle. Even when the U.S. economy is expanding, growth in production and employment does not occur continuously over the year. Rather, growth varies systematically across the different seasons. This pattern is called the seasonal cycle. Seasonality generally refers to fluctuations that recur with a frequency of less than a year. In the past, economic activity was highly seasonal because of the importance of farming. But even now, economies continue to exhibit significant seasonal fluctuations. As we will show in this article - and as has been known at least since Barsky and Miron (1989) — some sectors of the U.S. economy contract significantly during the winter or during the summer and expand significantly in the final quarter of the year. This cycle is driven by both weather and institutional factors, either of which affects supply (that is, the ability or willingness of firms to produce goods and services) or demand (that is, the willingness of consumers to pay for these goods and services).

To get a better sense of the seasonal patterns we have in mind, consider the following examples. First, building houses in the winter is difficult in cold regions, so the productivity of the construction industry is seasonal- low during the winter and higher during the rest of the year. As a result, this industry is organized to conduct most of its business during the spring, summer, and fall. Second, many people prefer to take time off during the summer to take advantage of the warm weather, but also because most schools are in recess then; this preference leads to lower work and production during this season relative to others. Third, during the traditional holiday season, spending by households significantly increases compared with the rest of the year.

Despite their magnitude, such seasonal fluctuations are typically ignored by researchers. Most analyses for the purposes of forecasting and policymaking or for academic research use so-called seasonally adjusted data - that is, data where seasonal fluctuations have been removed using a purely statistical procedure. ${ }^{1}$ 
A few papers, however, note that seasonal fluctuations are not only large, but also similar to business cycle fluctuations in several ways, such as the co-movement of economic time series. This suggests that one might learn about the business cycle from studying the seasonal cycle. Then again, seasonal fluctuations are more forecastable than typical business cycle fluctuations. This predictability creates incentives for households and firms to borrow or save to smooth economic fluctuations throughout the course of the year, if they so desire. ${ }^{2}$

We have two main goals for this article. Our first goal is to present some stylized facts about U.S. employment seasonality. We focus on employment because it is a key measure of economic activity that is well measured and available at a high frequency and at a fine level of disaggregation. In particular, we study the seasonal patterns of employment, measured monthly, for each industry in each state. We document some well-known facts, as well as one not-so-well-known fact - that the seasonality of U.S. employment appears to have decreased significantly since the $1960 \mathrm{~s}$. This decline is similar in some respects to the reduction in macroeconomic volatility that began in the mid-1980s and lasted until 2007—a period that macroeconomists have dubbed the "Great Moderation." Our second goal is to revisit the question of whether there is a relationship between the amplitude (or range) of the seasonal cycle and the amplitude of the business cycle. As we discuss in more detail later, some authors have argued, both theoretically and empirically, that industries or countries that are more seasonal ought to be more cyclical (that is, more sensitive to the business cycle) as well. We revisit this claim by using more-recent and more-disaggregated data. Our contribution here is to exploit variation across states in the extent of seasonality. We argue that this variation is largely driven by weather, at least for some industries. This allows us to study the relationship between seasonality and business cyclicality within an industry by comparing different states. By focusing on the United States, rather than comparing different countries, we also hold institutional and technological characteristics relatively constant. Our main finding is that there is no systematic relationship between the seasonality and cyclicality of employment: Some industries exhibit a negative relationship across states, while others exhibit a positive one; and for some, the relationship is statistically insignificant.

In the next section of our article, we document six stylized facts about the seasonal cycle of U.S. employment. After that, we explain how we study the relationship between seasonality and cyclicality, and discuss the results. To close, we present our conclusions and suggest directions for future research.

\section{Six facts about U.S. employment seasonality}

In this section, we document some stylized facts about U.S. employment seasonality. We chiefly use three sets of nonseasonally adjusted monthly employment data from the Current Employment Statistics (CES) survey - also known as the establishment or payroll survey — published by the U.S. Bureau of Labor Statistics (BLS). The BLS samples a large number of establishments and estimates the total number of people on the payroll during the so-called reference week - the week that includes the 12th day of the month. ${ }^{3}$ Our main data set reports employment for each of 13 industries $^{4}$ in 47 states $^{5}$ for the period 1990-2016. To complement our analysis by using longer time series, we also obtain nationwide industry-level data for the period 1939-2016 and state total employment data for the period 1956-2016. We summarize the main patterns we observed in the data as the following six facts. 
FIGURE 1

\section{Seasonal fluctuations in national employment}

A. Fluctuations in national employment, 1983-2016

percent

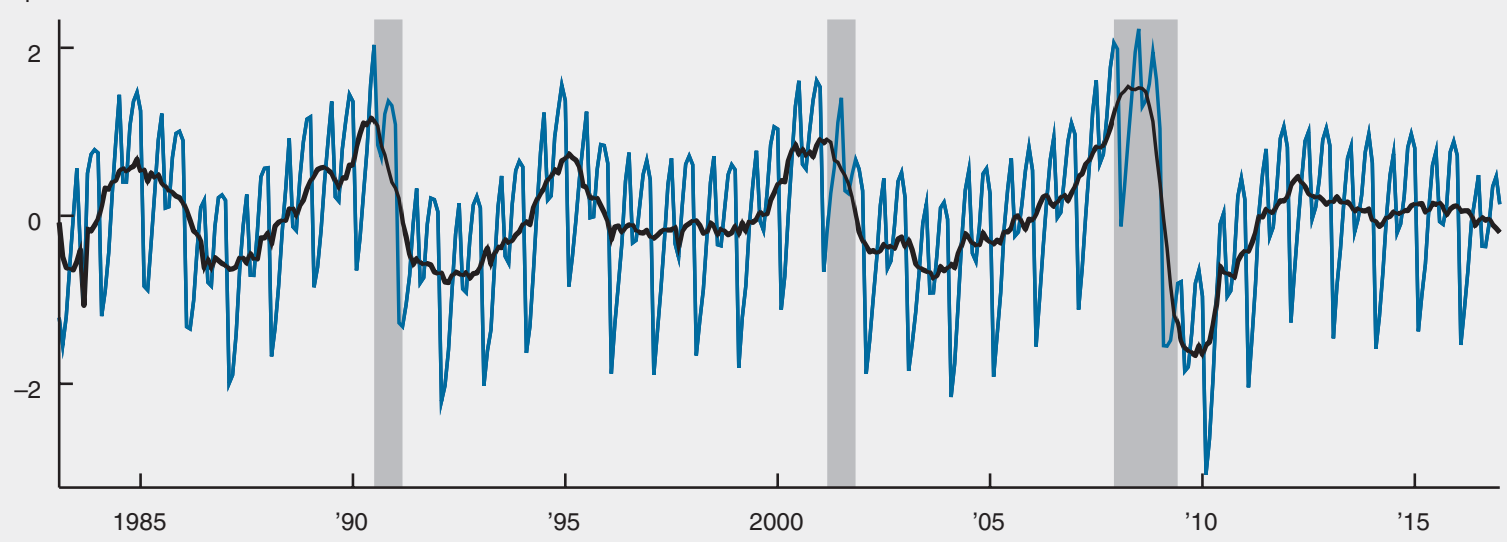

B. Estimated seasonal effects on employment, 1939-2016

percent

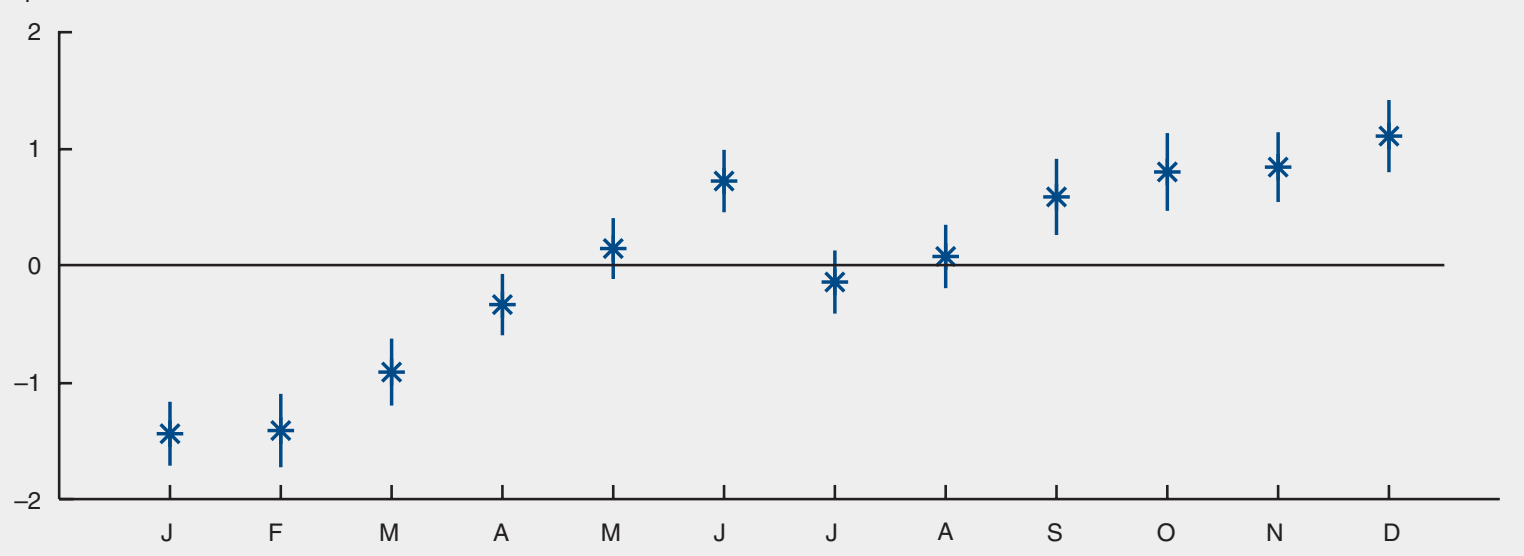

Notes: Panel A plots Hodrick-Prescott-filtered (HP-filtered) nonseasonally adjusted log national employment data (blue line) and HP-filtered seasonally adjusted log national employment data (black line). The shaded areas in panel A indicate official periods of recession as identified by the National Bureau of Economic Research. Panel B plots the point estimates of the monthly dummy coefficients $\left(\beta_{k}\right)$ from equation 1 (asterisks) for employment, together with plus and minus two-standard-error bands (vertical lines that run through the asterisks). See the text for further details.

Source: Authors' calculations based on data from the U.S. Bureau of Labor Statistics, Current Employment Statistics, from Haver Analytics.

\section{Fact 1: There is much seasonality in aggregate employment}

We start by studying aggregate employment. Panel A of figure 1 depicts aggregate (national) nonfarm employment — both nonseasonally adjusted and seasonally adjusted — since 1983. Both series are logged and detrended using the Hodrick-Prescott (HP) filter. ${ }^{6}$ The gray shaded areas are recessions, as defined by the National Bureau of Economic Research (NBER). The recessions generally correspond to periods when seasonally adjusted employment is contracting persistently. Because the series are logged, the units can be understood as (approximately) percentage change. The figure shows that seasonal fluctuations are about the same magnitude as business cycle fluctuations. Each year the range of variation in nonseasonally adjusted employment (blue line) is about 2 percent. The range of variation in seasonally adjusted employment (black line) is also about 2 percent during the 1990-91 and 2001 recessions and about 3 percent during the Great Recession of 2008-09. 


\section{Seasonal fluctuations in employment for selected industries, 1983-2016}

A. Construction

percent

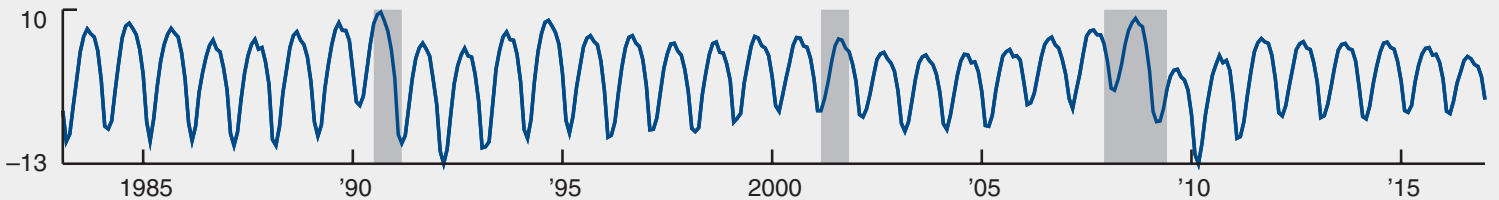

B. Manufacturing

percent

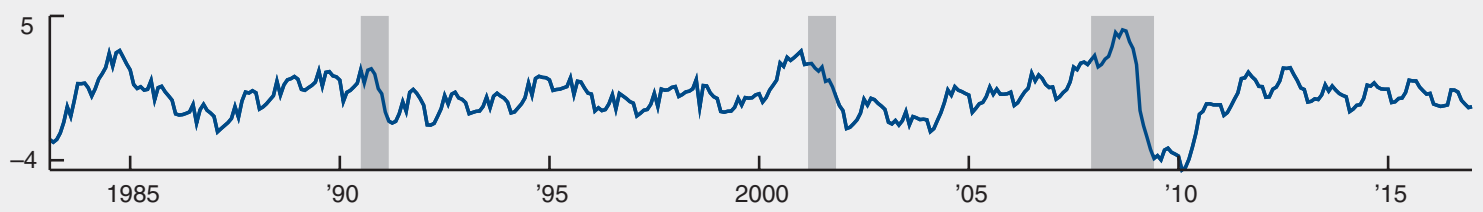

C. Retail trade

percent

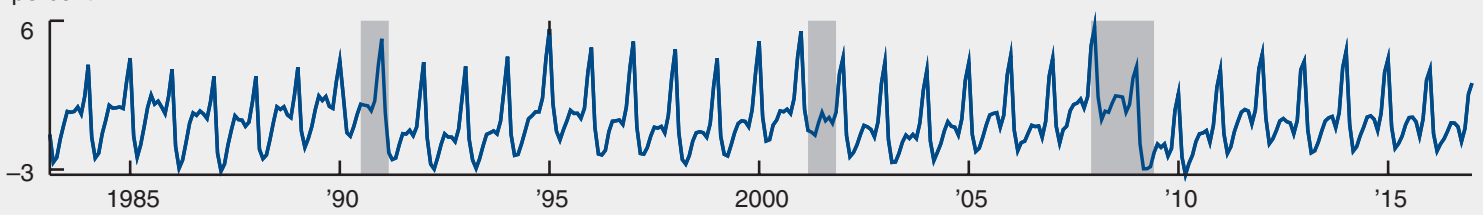

D. Government

percent

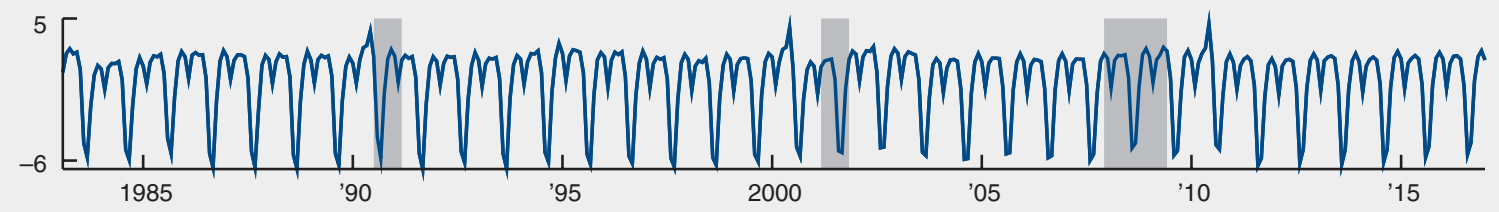

Notes: All industry employment data are nonseasonally adjusted, logged, and Hodrick-Prescott filtered. The shaded areas in each panel indicate official periods of recession as identified by the National Bureau of Economic Research. Source: Authors' calculations based on data from the U.S. Bureau of Labor Statistics, Current Employment Statistics, from Haver Analytics.

To measure more precisely the seasonal pattern of employment, we use a linear regression to estimate the effect of each month on employment using dummy variables:

1) $y_{t}=\sum_{k=1}^{12} \beta_{k} D_{k}+\varepsilon_{t}$,

where $y_{t}$ is HP-filtered log national employment (nonseasonally adjusted) at time $t, \beta_{k}$ is a dummy coefficient for month $k, D_{k}$ is a monthly dummy for month $k$, and $\varepsilon_{t}$ is an error term. ${ }^{7}$

Panel B of figure 1 reports the estimated monthly effects, or monthly dummy coefficients $\left(\beta_{k}\right)$, from equation 1 (shown as the asterisks) for employment, together with plus and minus two-standard-error confidence bands (shown as the vertical lines that run through the asterisks), for the period 1939-2016. 
FIGURE 3

Estimated seasonal effects on employment for selected industries, 1939-2016

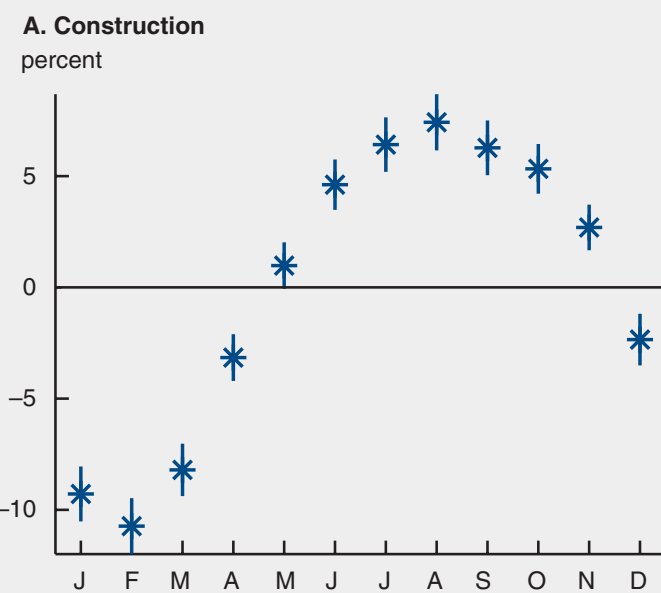

B. Manufacturing

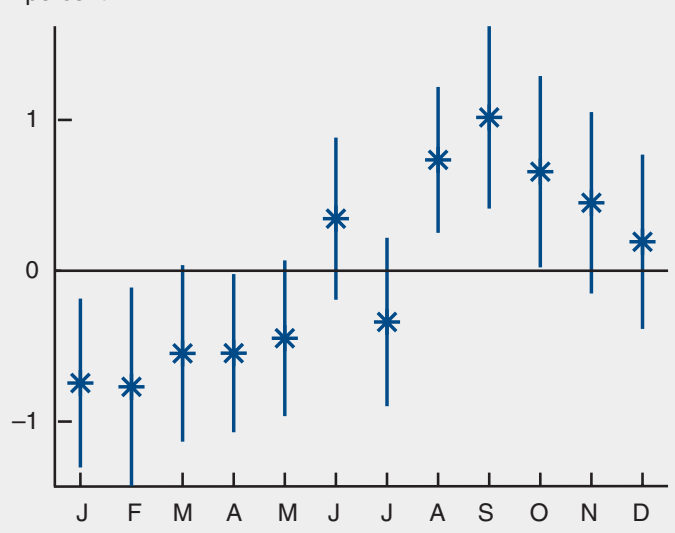

C. Retail trade

D. Government

percent

percent
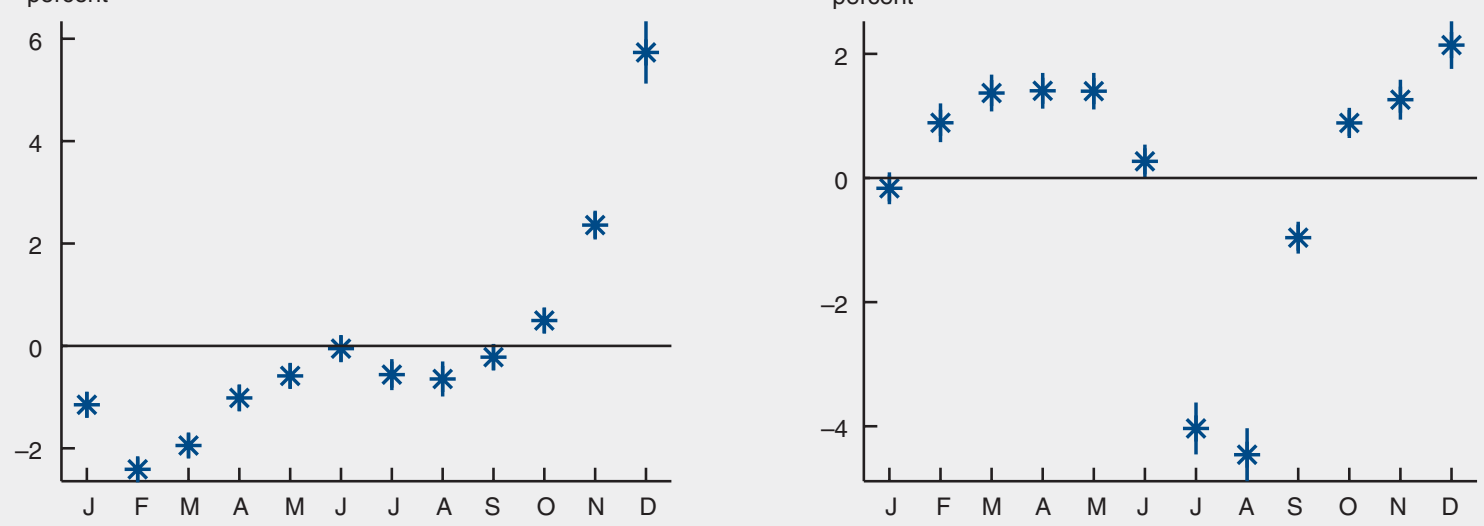

Notes: The figure plots the point estimates of the monthly dummy coefficients $\left(\beta_{i k}\right)$ from equation 2 (asterisks) for employment in four selected industries, together with plus and minus two-standard-error bands (vertical lines that run through the asterisks). See the text for further details.

Source: Authors' calculations based on data from the U.S. Bureau of Labor Statistics, Current Employment Statistics, from Haver Analytics.

National employment is more than 1 percent below the annual average in January and February and then rises steadily until June, before dropping back in July and then resuming its rise until reaching the peak in December. Panel B confirms that the amplitude of seasonal fluctuations in employment is on average over 2 percentage points - the difference between the December and January dummies.

\section{Fact 2: There is much heterogeneity in the seasonality of employment across industries}

We next measure the seasonality of employment for each industry. Figure 2 presents time series since 1983 of HP-filtered log employment data for four industries: construction, manufacturing, retail trade, and government (which includes federal, state, and local governments). We choose these industries because they provide interesting examples of the different existing patterns. Most industries display seasonal fluctuations, though the magnitudes and shapes of the fluctuations differ. At one extreme, the range of seasonal variation in construction employment (panel A) is quite large, close to 20 percentage points. For retail trade and 


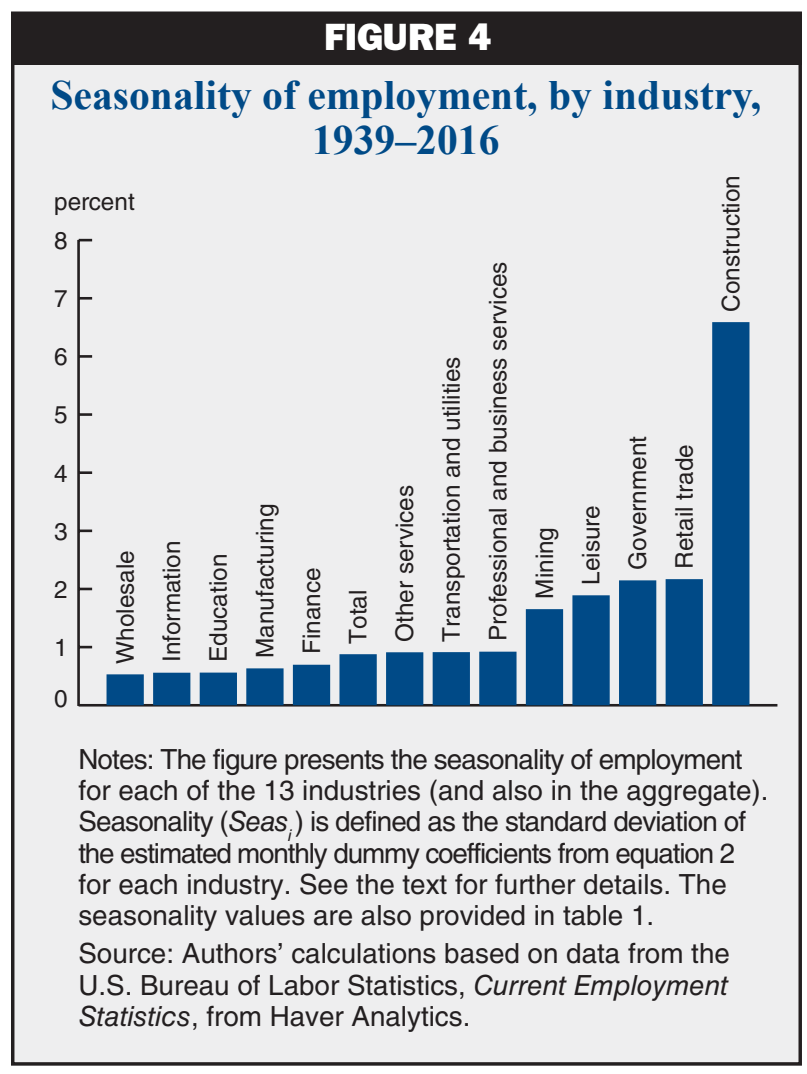

government (panels $\mathrm{C}$ and $\mathrm{D}$, respectively), the range is only 6 to 8 percentage points, and manufacturing (panel B) is even less seasonal. The patterns of seasonality also differ across industries - for instance, construction has a smooth cycle, while retail trade has a positive spike and government a negative spike. ${ }^{8}$

To measure the seasonal cycle for each industry, we estimate again a linear regression on monthly dummies. This is the exact same procedure as in equation 1, but with HP-filtered log industry employment (instead of national employment) regressed on monthly dummies:

2) $y_{i t}=\sum_{k=1}^{12} \beta_{i k} D_{k}+\varepsilon_{i t}$.

In this equation, $y_{i t}$ is HP-filtered log employment (nonseasonally adjusted) of industry $i$ at time $t, \beta_{i k}$ is a dummy coefficient for industry $i$ in month $k, D_{k}$ is a monthly dummy for month $k$, and $\varepsilon_{i t}$ is an error term.

Figure 3 plots the estimated monthly effects, or monthly dummy coefficients $\left(\beta_{i k}\right)$, for the four industries based on the regression results from equation 2 , together with the plus and minus two-standard-error bands. ${ }^{9}$

Construction employment (figure 3, panel A) reaches a trough in February-when employment is about 10 percent below the annual average — and a peak around August—when employment is about 7 percent above the annual average. For manufacturing employment (panel B), the trough is also in the winter quarter, but the size of the decline relative to the annual average is small-less than 1 percent. Employment in the government sector (panel D) is at its lowest during July and August, when it declines by around 4 percent, apparently because of schools closing in the summer and opening in the fall. Employment in the retail trade industry (panel C) has a very different seasonal pattern: It spikes above the annual average by almost 6 percent in December, during the holiday season, before falling back immediately thereafter.

To summarize the amplitude of the seasonal cycle, we define a measure of employment seasonality, denoted Seas ${ }_{i}$, which is the standard deviation across the 12 months of the estimated monthly dummies $\left(\beta_{i k}\right)$ from equation 2. Formally, $\operatorname{Seas}_{i}=\sqrt{\frac{1}{12} \sum_{k=1}^{12} \beta_{i k}^{2}}$, where we have used the fact that $\sum_{k=1}^{12} \beta_{i k}=0$, since the HP-filtered series has a mean of zero. This measures the predictable seasonal variation over the year. Figure 4 reports employment seasonality for each of our 13 industries. By far the most seasonal industry is construction, with a seasonality value of 6.59 percent, followed by retail trade and government (whose seasonality values are 2.17 percent and 2.15 percent, respectively). The least seasonal industries are wholesale, information, and education, with seasonality values of 0.53 percent, 0.56 percent, and 0.56 percent, respectively. ${ }^{10}$ Table 1 reports the seasonality values for all 13 industries (see the fourth column of data). Additionally, table 1 reports the share of the employment in each industry in 1950 and in 2000, as well as the volatility and business cyclicality of employment for each industry. Volatility is a measure of the total variation of the industry employment series (nonseasonally adjusted). Formally, it is defined as the standard deviation 
TABLE 1

Summary statistics for national industry-level employment

\begin{tabular}{|c|c|c|c|c|c|}
\hline Industry & $\begin{array}{c}\text { Share } \\
\text { in } 1950\end{array}$ & $\begin{array}{l}\text { Share } \\
\text { in } 2000\end{array}$ & Volatility & Seasonality & Cyclicality \\
\hline & \multicolumn{5}{|c|}{ 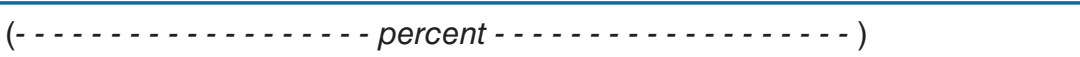 } \\
\hline Construction & 5.09 & 5.15 & 8.12 & 6.59 & 2.14 \\
\hline Mining & 2.02 & 0.45 & 4.51 & 1.65 & 1.37 \\
\hline Manufacturing & 30.24 & 13.19 & 2.58 & 0.63 & 1.82 \\
\hline Education & 4.84 & 11.53 & 1.25 & 0.56 & 0.34 \\
\hline Finance & 4.12 & 5.93 & 1.07 & 0.70 & 0.22 \\
\hline Information & 3.59 & 2.71 & 1.92 & 0.56 & 1.12 \\
\hline Leisure & 6.24 & 8.94 & 2.83 & 1.89 & 0.54 \\
\hline $\begin{array}{l}\text { Professional and } \\
\text { business services }\end{array}$ & 6.55 & 12.53 & 1.42 & 0.92 & 0.74 \\
\hline Retail trade & 10.33 & 11.59 & 2.49 & 2.17 & 0.56 \\
\hline Other services & 1.89 & 3.93 & 1.19 & 0.91 & 0.37 \\
\hline Transportation and utilities & 6.38 & 3.80 & 1.56 & 0.91 & 0.73 \\
\hline Wholesale & 5.09 & 4.54 & 1.42 & 0.53 & 0.54 \\
\hline Government & 13.63 & 15.70 & 2.49 & 2.15 & 0.40 \\
\hline Total employment & 100 & 100 & 1.53 & 0.88 & 1.00 \\
\hline
\end{tabular}

Notes: The first and second columns of data report the share of employment in each industry in 1950 and 2000, respectively. These two columns do not total exactly to 100 percent because of rounding. The third column reports industry volatility-that is, the standard deviation of the Hodrick-Prescott-filtered log of employment (nonseasonally adjusted). The fourth column reports the measure of seasonality $\left(\right.$ Seas $\left._{i}\right)$ - the standard deviation of the estimated monthly dummy coefficients from equation 2 . The fifth column reports the measure of cyclicality-the coefficient $\gamma_{i}$ from equation 4 . The values in the final three columns are based on data over the period 1939-2016.

Source: Authors' calculations based on data from the U.S. Bureau of Labor Statistics, Current Employment Statistics, from Haver Analytics.

of the HP-filtered logged series. Volatility can be decomposed into seasonal variation-which is our seasonality measure - and nonseasonal variation. So, the difference between volatility and seasonality is a measure of nonseasonal variation. As the table shows, for many series, seasonality is only a little smaller than volatility, so the nonseasonal component is relatively small. We discuss cyclicality later on.

\section{Fact 3: For some industries, there is much heterogeneity in the amplitude of the seasonal cycle across states}

Do the patterns we have described previously apply equally to all states? We now document that for some industries there is significant heterogeneity in employment seasonality across states. We estimate patterns of seasonality for each industry in each state separately using a similar linear regression:

3) $y_{i s t}=\sum_{k=1}^{12} \beta_{i s k} D_{k}+\varepsilon_{i s t}$. 

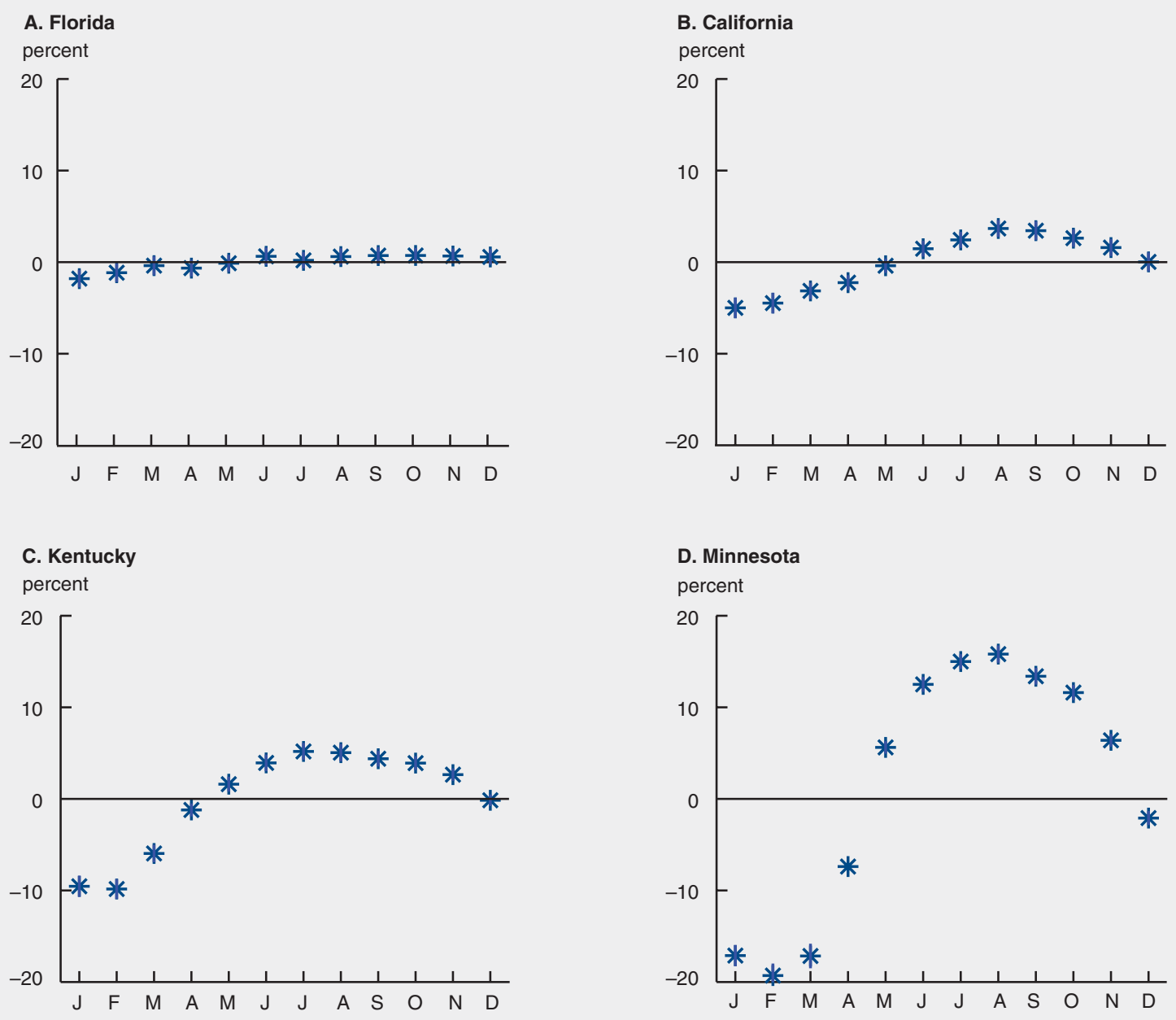

Notes: The figure plots the point estimates of the monthly dummy coefficients $\left(\beta_{\text {isk }}\right)$ from equation 3 (asterisks) for construction employment in four selected states, together with plus and minus two-standard-error bands (vertical lines, most of which are not viewable given their small size, that run through the asterisks). See the text for further details. Source: Authors' calculations based on data from the U.S. Bureau of Labor Statistics, Current Employment Statistics, from Haver Analytics.

In this equation, $y_{i s t}$ is HP-filtered $\log$ employment (nonseasonally adjusted) of industry $i$ in state $s$ at time $t$; $\beta_{i s k}$ is a dummy coefficient for industry $i$ in state $s$ and month $k ; D_{k}$ is a monthly dummy for month $k$; and $\varepsilon_{i s t}$ is an error term.

Figure 5 displays the monthly dummy coefficients $\left(\beta_{i s k}\right)$ for the construction industry in four different states: Florida, California, Kentucky, and Minnesota. The amplitude of the seasonal cycle of construction employment is very different in these states. Florida is less seasonal than California, which is less seasonal than Kentucky, which is itself less seasonal than Minnesota. Quantitatively, construction employment in Minnesota is 20 percent below the annual average at its trough in February, whereas Kentucky's trough is only about 10 percent below the annual average, California's 5 percent, and Florida's 2 percent. These differences likely reflect the impact of weather. To verify this, we plot in figure 6 , for each state, our measure of the seasonality of employment ${ }^{11}$ for the construction industry against the average January temperature. There is a strong negative correlation: Colder states have more-seasonal construction employment. 


\section{Average temperature in January \\ versus seasonality of construction employment for states}

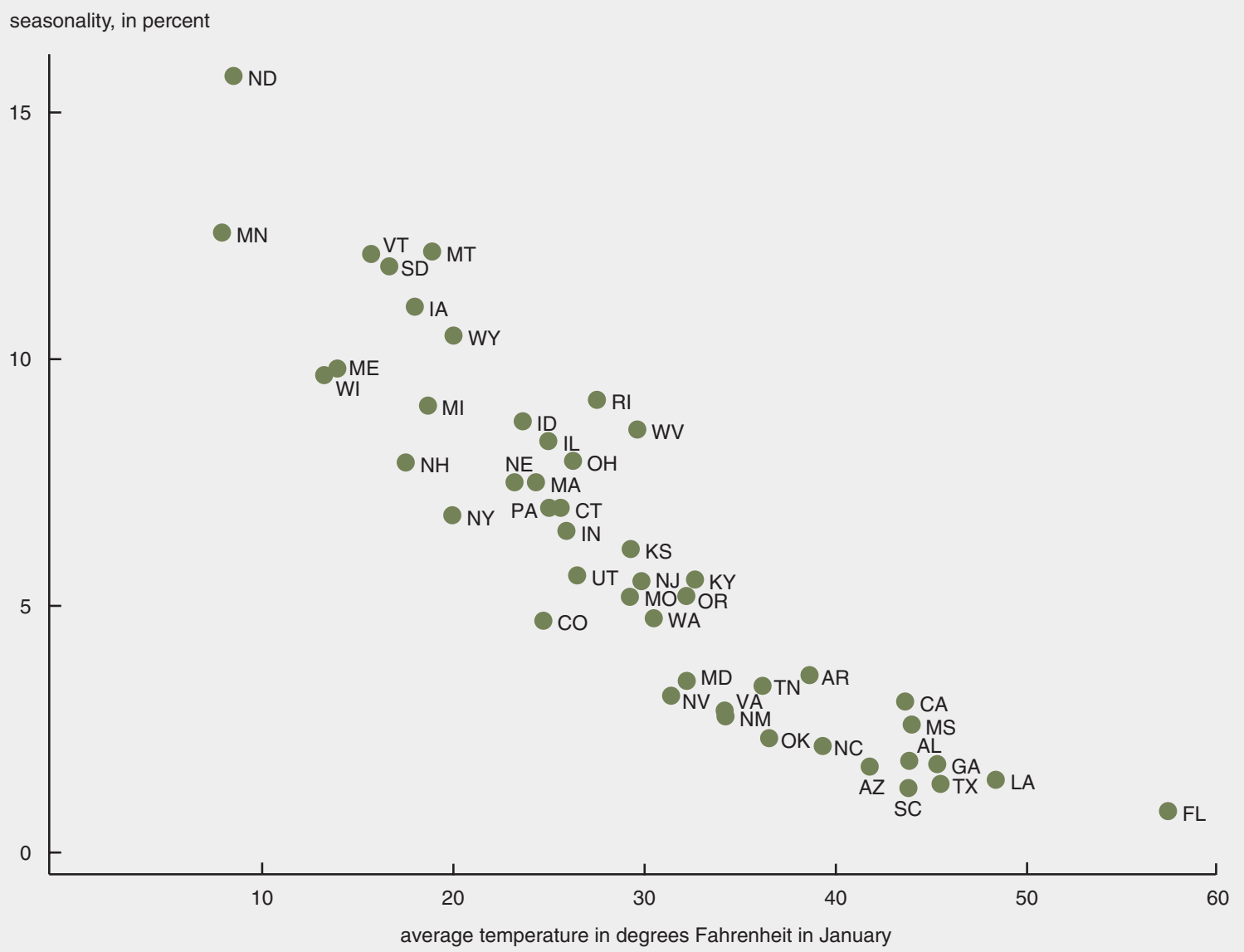

Notes: The measure of seasonality $\left(S_{e a s_{i s}}\right.$ ) on the vertical axis is the standard deviation of the estimated monthly dummy coefficients from equation 3 for construction employment. For the 47 states, seasonality is based on data over the period 1990-2016, and the average temperature in January is based on data over the period 1950-2016. See the text for further details.

Sources: Authors' calculations based on data from the U.S. Bureau of Labor Statistics, Current Employment Statistics, and U.S. Department of Commerce, National Oceanic and Atmospheric Administration, from Haver Analytics.

Figure 7 also displays the monthly dummy coefficients $\left(\beta_{i s k}\right)$ for the mining industry in four states: Colorado, Utah, North Dakota, and Idaho. The seasonality of mining employment is also very different across states, ranging from very low for Colorado to substantial for Idaho. However, the differences in mining employment seasonality are not as well explained by the January weather, as can be seen in figure 8 (for instance, notice that Colorado and Idaho have about the same average temperature in January, but mining employment seasonality is quite different in these two states).

\section{Fact 4: While for some industries, there is much heterogeneity in the amplitude of the seasonal cycle across states, for others, there is little}

As we showed previously, the amplitude of the seasonal cycle in construction is very different across states, and is well explained by winter weather. However, other industries show little variation in seasonality across states. This is illustrated in figure 9. Retail employment is seasonal: There's a December peak each year. Yet, it turns out that all states have a December retail employment peak of roughly the same size. 


\section{FIGURE 7}

\section{Estimated seasonal effects on mining employment in selected states, 1990-2016}
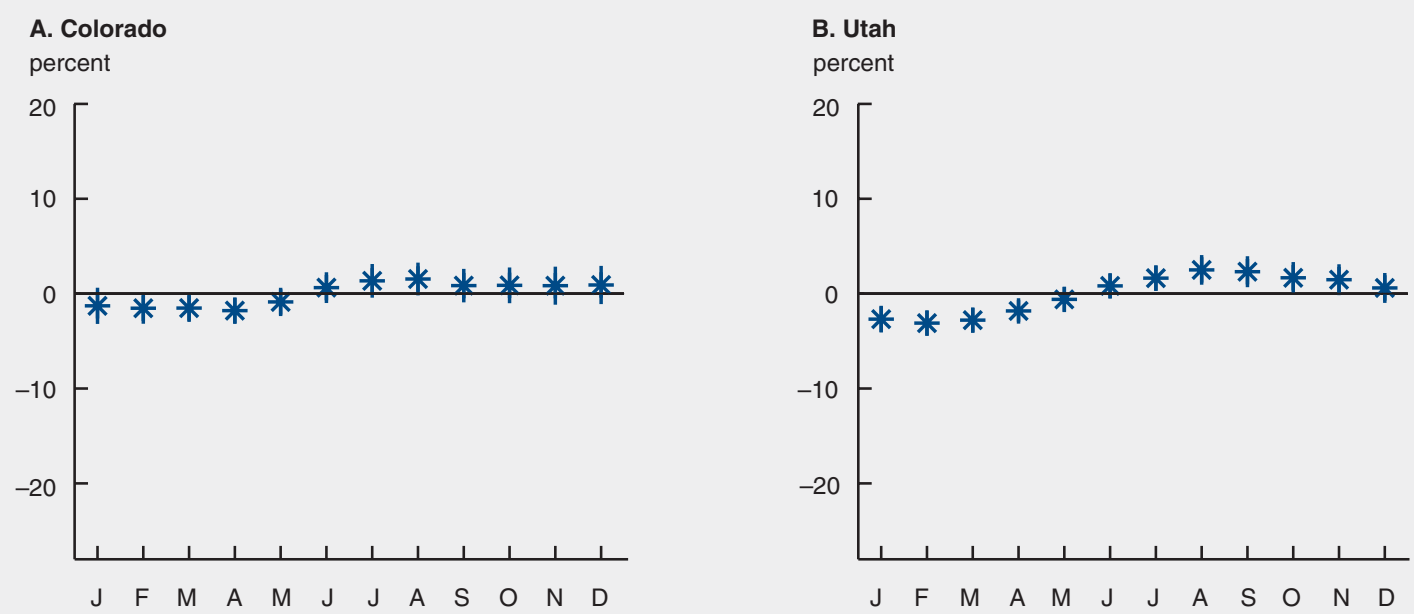

\section{North Dakota}

percent
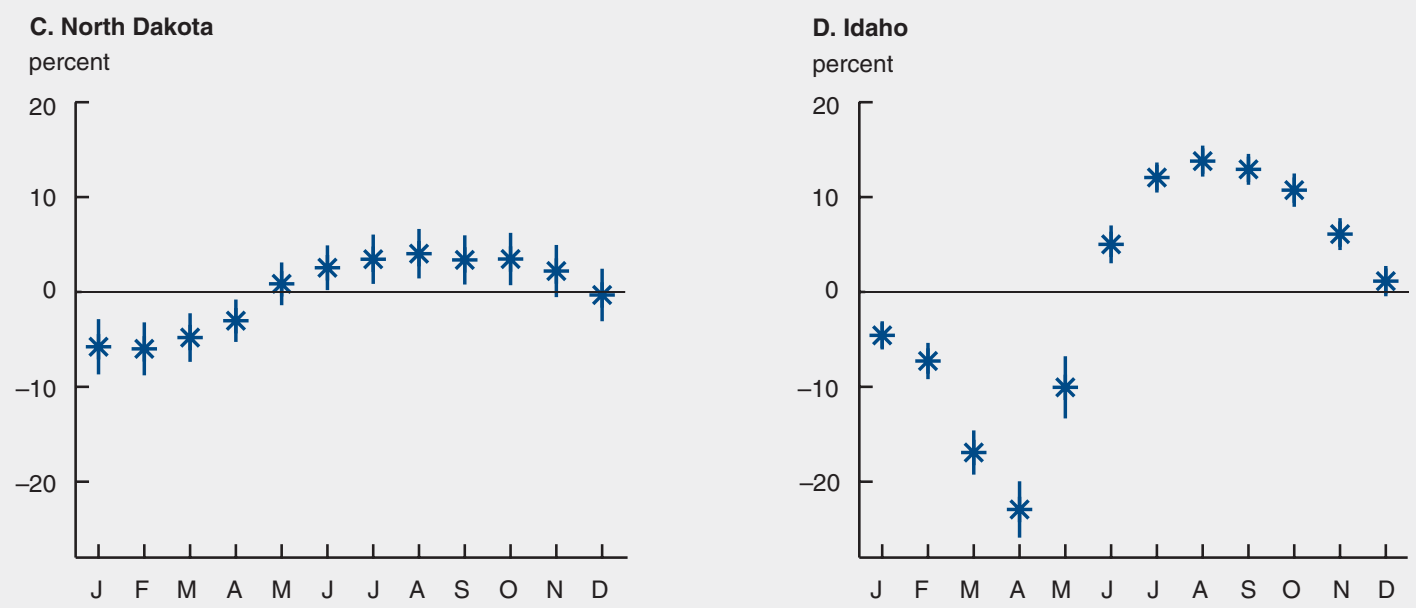

Notes: The figure plots the point estimates of the monthly dummy coefficients $\left(\beta_{\text {isk }}\right)$ from equation 3 (asterisks) for mining employment in four selected states, together with plus and minus two-standard-error bands (vertical lines that run through the asterisks). See the text for further details.

Source: Authors' calculations based on data from the U.S. Bureau of Labor Statistics, Current Employment Statistics, from Haver Analytics.

Apparently, the importance of the traditional holiday season to retailers is generally the same throughout the United States.

Table 2 presents a measure of heterogeneity in seasonality by calculating, for each industry, the standard deviation across states of our seasonality measure. The seasonality measure is shown in table 1 for each industry. According to these measures, construction employment is highly seasonal (6.59 percent) and highly heterogeneous in seasonality (3.67 percent). Mining employment is relatively seasonal (1.65 percent) and highly heterogeneous in seasonality (4.11 percent), and leisure industry employment is also relatively seasonal (1.89 percent) and highly heterogeneous in seasonality (2.81 percent). For example, for the leisure industry, New Hampshire, Wyoming, and Maine have 10 percent and above seasonality of employment, whereas Nevada, California, Louisiana, and Alabama have 2 percent or below seasonality; for mining, the seasonality of employment ranges from 16 percent for Rhode Island and Maine to less than 1 percent for Florida and South Carolina. In contrast, employment in both retail trade and government is relatively seasonal with a 
FIGURE 8

\section{Average temperature in January \\ versus seasonality of mining employment for states}

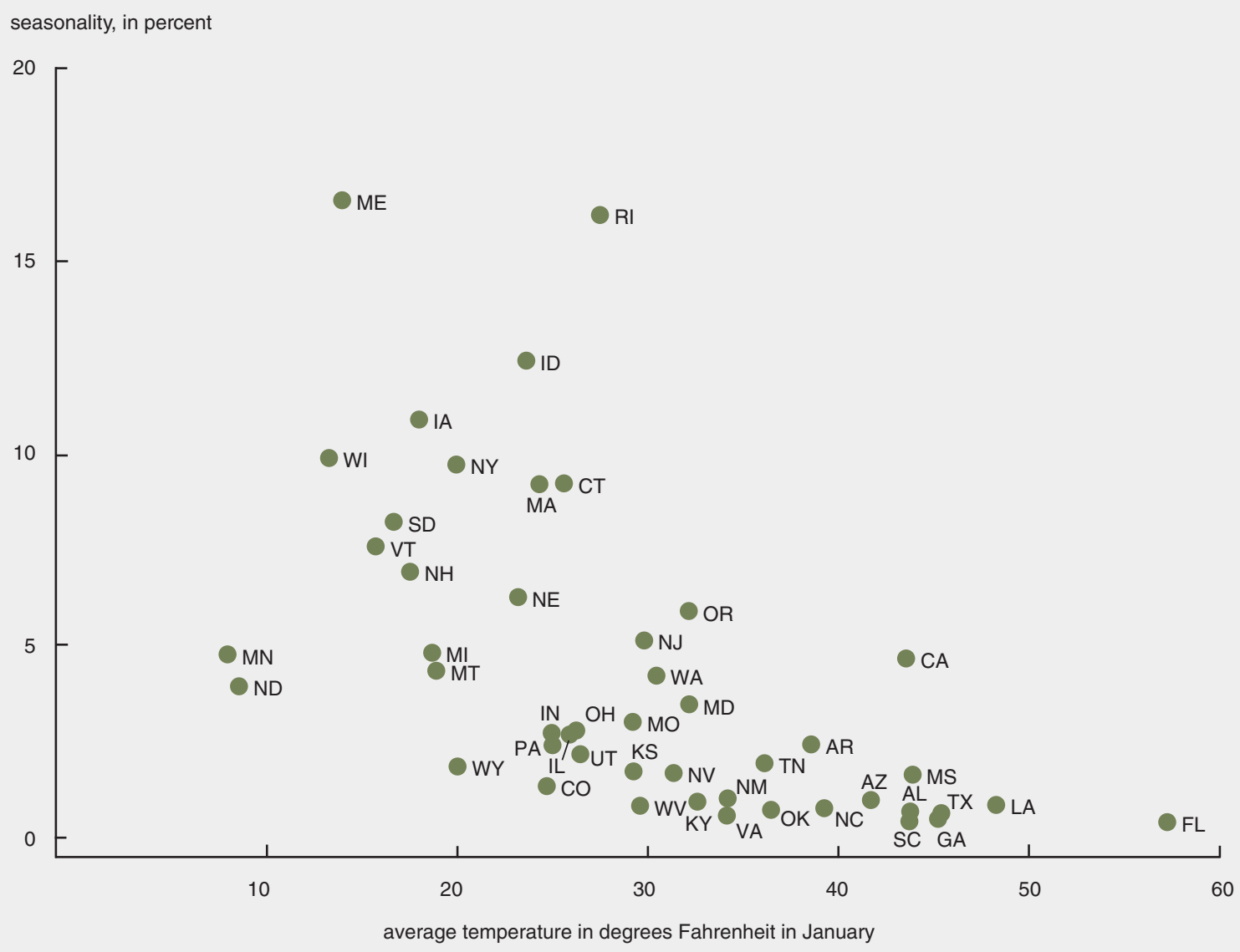

Notes: The measure of seasonality $\left(\right.$ Seas $_{i s}$ ) on the vertical axis is the standard deviation of the estimated monthly dummy coefficients from equation 3 for mining employment. For the 47 states, seasonality is based on data over the period 1990-2016, and the average temperature in January is based on data over the period 1950-2016. See the text for further details.

Sources: Authors' calculations based on data from the U.S. Bureau of Labor Statistics, Current Employment Statistics, and U.S. Department of Commerce, National Oceanic and Atmospheric Administration, from Haver Analytics.

low heterogeneity in seasonality across all states. The rest of the industries have a low seasonality of employment and a low heterogeneity in seasonality. Table 3 summarizes this taxonomy of industries.

\section{Fact 5: There is much heterogeneity in the pattern of seasonal fluctuations in employment across states even for the same industry}

Besides the differences in the amplitude of seasonal employment fluctuations, states also exhibit different seasonal patterns (or timings) across the year - that is, the seasons during which they expand or contract are not always the same. We illustrate this in figure 10 by depicting the estimated monthly dummy coefficients for the leisure industry in four selected states. Most states have a pattern similar to what is observed in California and Maine: high employment in the leisure industry in the summer and relatively lower employment the rest of the year. But some states have markedly different patterns. For instance, Florida reaches its employment peak in March and April. Vermont has twin peaks, with high employment in both the winter and summer and lower employment in the spring and fall. These patterns likely reflect the effects 
Seasonality of employment in selected industries, by state, 1990-2016

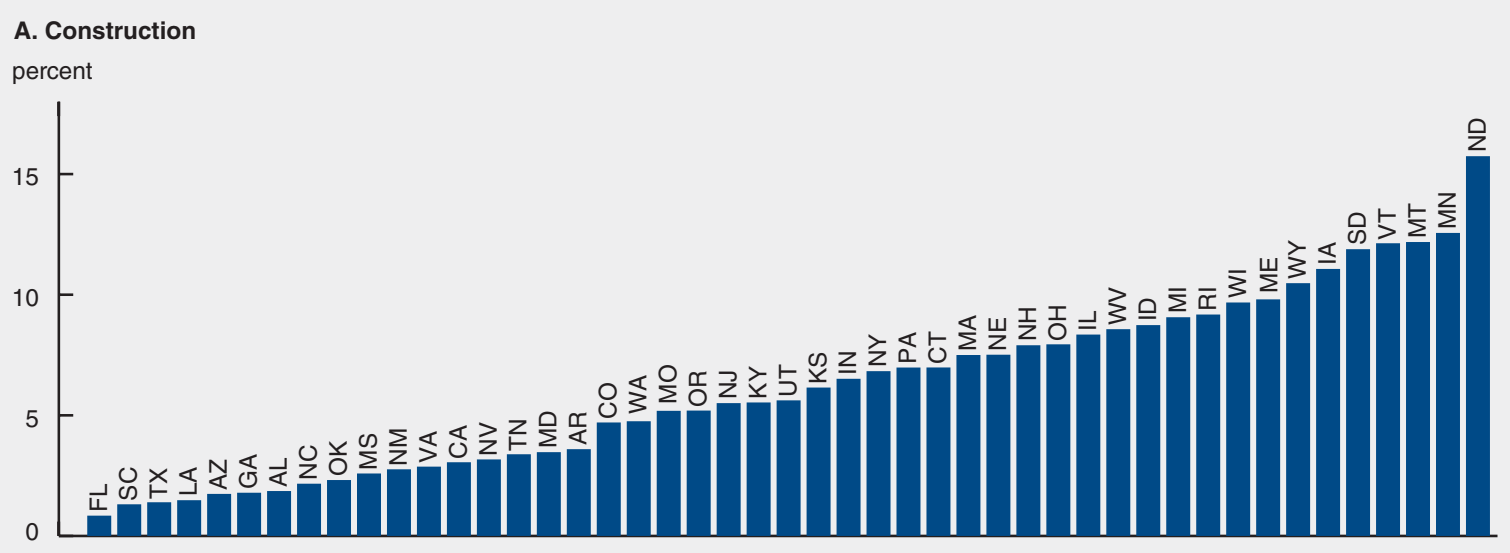

B. Retail trade

percent

Notes: The figure presents for each of the 47 states the seasonality of employment for the construction industry (panel A) and for the retail trade industry (panel B). Seasonality $\left(\right.$ Seas $_{\text {is }}$ ) is defined as the standard deviation of the estimated monthly dummy coefficients from equation 3 for each industry. See the text for further details.

Source: Authors' calculations based on data from the U.S. Bureau of Labor Statistics, Current Employment Statistics, from Haver Analytics.

of tourism and other related activities, which are strongest during the winter in Florida, but are strong both in the winter and in the summer in Vermont.

\section{Fact 6: The amplitude of seasonal fluctuations in employment decreased between the 1960 s and the mid-1980s but has remained approximately the same since}

The patterns of seasonality that we have documented so far are not mathematical constants - they may evolve with advances in technology and changes in preferences. For example, technological progress in the construction industry may have reduced the negative effect of winter on productivity for that industry. The shift to electronic commerce may also have led to a reduction in seasonality in retail, though it may have been offset by higher seasonality in the transportation and warehousing sector. To illustrate this, we display in figure 11 employment for couriers and messengers ${ }^{12}$ between 1990 and 2017. Over this period, there is a clear increase in the amplitude of the seasonal (December) peak. In the 1990s, the peak was around 50,000 extra jobs. Recently, the peak has been over 200,000 jobs. 
TABLE 2

Dispersion and correlation of the seasonality and

cyclicality of employment across states, by industry, 1990-2016

\begin{tabular}{|c|c|c|c|}
\hline Industry & $\begin{array}{c}\text { Standard } \\
\text { deviation } \\
\text { of seasonality }\end{array}$ & $\begin{array}{c}\text { Standard } \\
\text { deviation } \\
\text { of cyclicality }\end{array}$ & $\begin{array}{l}\text { Correlation } \\
\text { between seasonality } \\
\text { and cyclicality }\end{array}$ \\
\hline \multicolumn{4}{|c|}{ (percent) } \\
\hline Construction & 3.67 & 0.82 & -0.13 \\
\hline Mining & 4.11 & 1.37 & 0.14 \\
\hline Manufacturing & 0.52 & 0.45 & 0.24 \\
\hline Education & 0.50 & 0.14 & -0.20 \\
\hline Finance & 0.22 & 0.30 & -0.17 \\
\hline Information & 0.24 & 0.62 & 0.04 \\
\hline Leisure & 2.81 & 0.32 & -0.16 \\
\hline Professional and business services & 0.69 & 0.37 & 0.02 \\
\hline Retail trade & 0.39 & 0.28 & 0.27 \\
\hline Other services & 0.60 & 0.51 & 0.15 \\
\hline Transportation and utilities & 0.69 & 0.38 & -0.19 \\
\hline Wholesale & 0.32 & 0.33 & -0.52 \\
\hline Government & 1.37 & 0.19 & 0.06 \\
\hline Total & 0.40 & 0.23 & -0.09 \\
\hline
\end{tabular}

Notes: For each industry, the table reports the standard deviation across states of the seasonality measure $\left(\right.$ Seas $\left._{i s}\right)$, the standard deviation across states of the cyclicality measure $\left(\gamma_{i s}\right)$, and the correlation across states between our seasonality and cyclicality measures. See the text for further details.

13 Source: Authors' calculations based on data from the U.S. Bureau of Labor Statistics, Current Employment Statistics, from Haver Analytics.

\section{TABLE 3}

Classification of industries according to magnitude of employment seasonality and heterogeneity in seasonality across states

High seasonality

\begin{tabular}{|c|c|c|}
\hline $\begin{array}{l}\text { High heterogeneity } \\
\text { in seasonality }\end{array}$ & Construction, leisure, and mining & None \\
\hline $\begin{array}{l}\text { Low heterogeneity } \\
\text { in seasonality }\end{array}$ & Retail trade and government & $\begin{array}{l}\text { Information, education, wholesale, } \\
\text { transportation and utilities, finance, } \\
\text { professional and business services, } \\
\text { other services, and manufacturing }\end{array}$ \\
\hline
\end{tabular}

Source: Authors' analysis based on data from the U.S. Bureau of Labor Statistics, Current Employment Statistics, from Haver Analytics. 


\section{Estimated seasonal effects on leisure industry employment in selected states, 1990-2016}
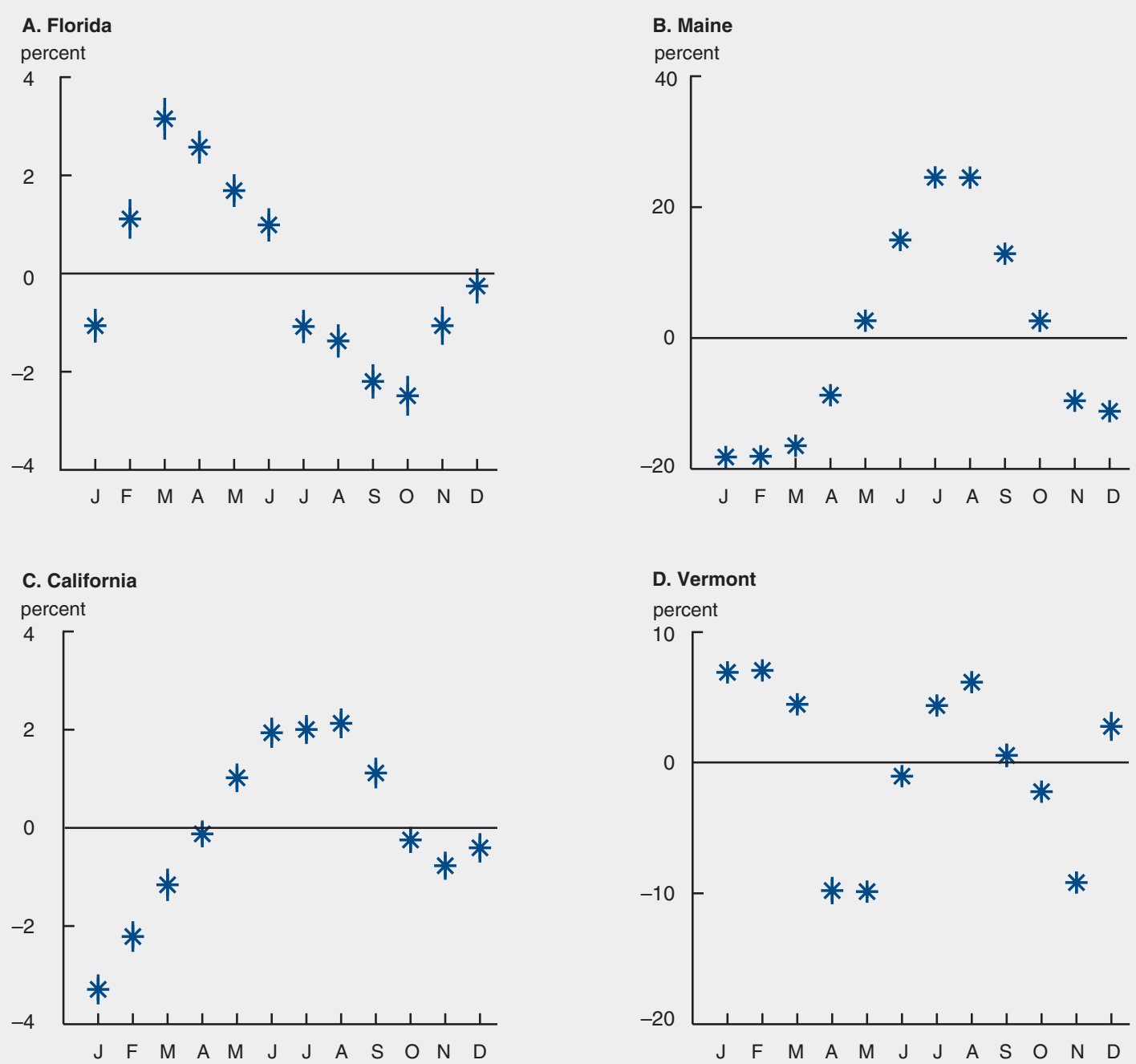

Notes: The figure plots the point estimates of the monthly dummy coefficients $\left(\beta_{i s k}\right)$ from equation 3 (asterisks) for leisure industry employment for four selected states, together with plus and minus two-standard-error bands (vertical lines that run through the asterisks). See the text for further details.

Source: Authors' calculations based on data from the U.S. Bureau of Labor Statistics, Current Employment Statistics, from Haver Analytics.

To measure systematically the changes in seasonality, we estimated equation 1 on rolling time windows of ten years. Figure 12 depicts this rolling measure of seasonality (the standard deviation of the estimated monthly dummy coefficients from equation 1) for national nonfarm employment over the period 19502016. This figure starts in 1955 and ends in 2011 because we use ten years of data to measure seasonality: We need to have data for five years on both sides of each point plotted. So, for instance, the value reported in this figure for January 1960 is the seasonality estimated over the ten-year period from January 1955 through December 1964. There is a sharp decline in seasonality from the 1960s to the mid-1980s, followed by a stabilization. Seasonality is reduced by around a third, falling from around 1.2 percent to less than 0.8 percent (a decrease of over 0.4 percentage points). ${ }^{13}$ 
FICURE 11

Employment in the couriers and messengers industry, 1990-2017

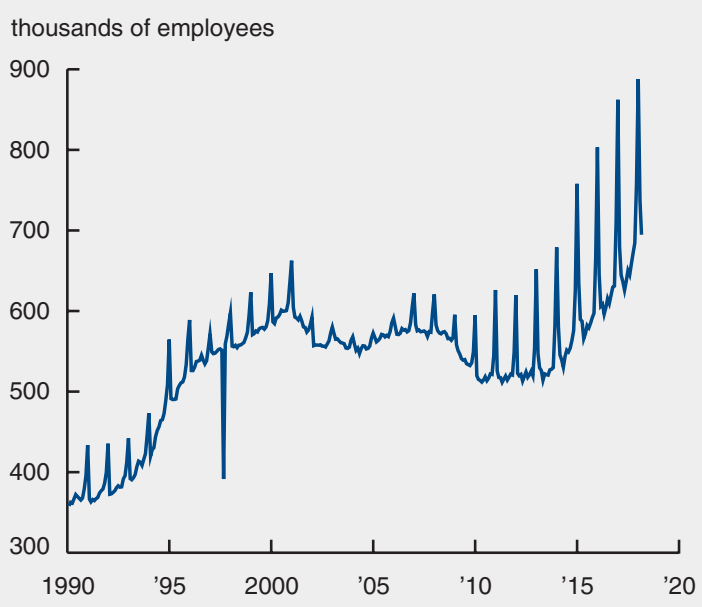

Note: The couriers and messengers industry employment data are nonseasonally adjusted.

Source: Authors' calculations based on data from the U.S. Bureau of Labor Statistics, Current Employment Statistics, from Haver Analytics.
FIGURE 12

Rolling measure of national

employment seasonality, 1950-2016

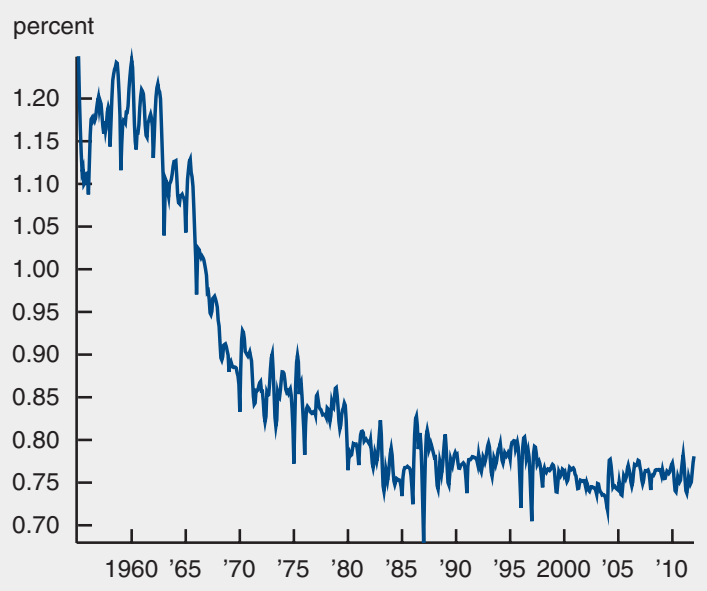

Notes: The figure depicts the standard deviation of the estimated monthly dummy coefficients from equation 1 using ten-year rolling windows. See the text for further details.

Source: Authors' calculations based on data from the U.S. Bureau of Labor Statistics, Current Employment Statistics, from Haver Analytics.

It is also interesting to look at the different patterns of shifting seasonality among industries or states; to do that, we plot the rolling measure of seasonality of employment for selected industries and states in figures 13 and 14, respectively. Like figure 12, figure 13 begins in 1955 and ends in 2011, given the design of the rolling measure as explained previously. As shown in figure 13, the seasonality of employment in construction declined by over half between the 1960 s and the 2000s, from over 9 percent to below 4 percent, while the seasonality of employment in the government sector increased substantially by about 1 percentage point between the late 1960s and the 1990s. Retail trade employment experienced a large decline in its seasonality from the beginning of our sample until the 1980s. The seasonality of manufacturing employment also fell. Table 4 reports the results of the rolling measure in 1960 and 2010 for all 13 industries, as well as the changes between those years. The measured decline in the seasonality of employment in the construction industry is consistent with technological improvements that make construction less seasonal. While construction accounts for a significant share of the decline in total seasonality, it does not explain nearly everything. One can see this by comparing figures 12 and 13: The timing of the decline in seasonality of construction employment does not match closely the timing of the decline in seasonality of aggregate employment. Moreover, mechanically, the share of total employment accounted for by construction has stayed roughly stable at about 5 percent, so the 5.14 percentage point decline in the seasonality of construction employment only accounts for about 0.26 percentage points (that is, $0.05 \times 5.14$ percentage points) of the total 0.47 percentage point decline in the seasonality of aggregate employment. Other important contributors to this decline are changes in the seasonality of employment in manufacturing, retail trade, wholesale, finance, information, and other services.

Turning to figure 14, we see that Florida and Minnesota have experienced large declines in the seasonality of employment since the 1960s. (Figure 14 covers the period 1956-2016, but it begins in 1961 and ends in 2011, given the design of the rolling measure as explained before.) However, other states such as Arizona, Illinois, and Texas had no decline or even an increase in seasonality. Overall, we find that between the 1950s and 2010s, 44 states experienced a decline in seasonality, and only three experienced an increase. 


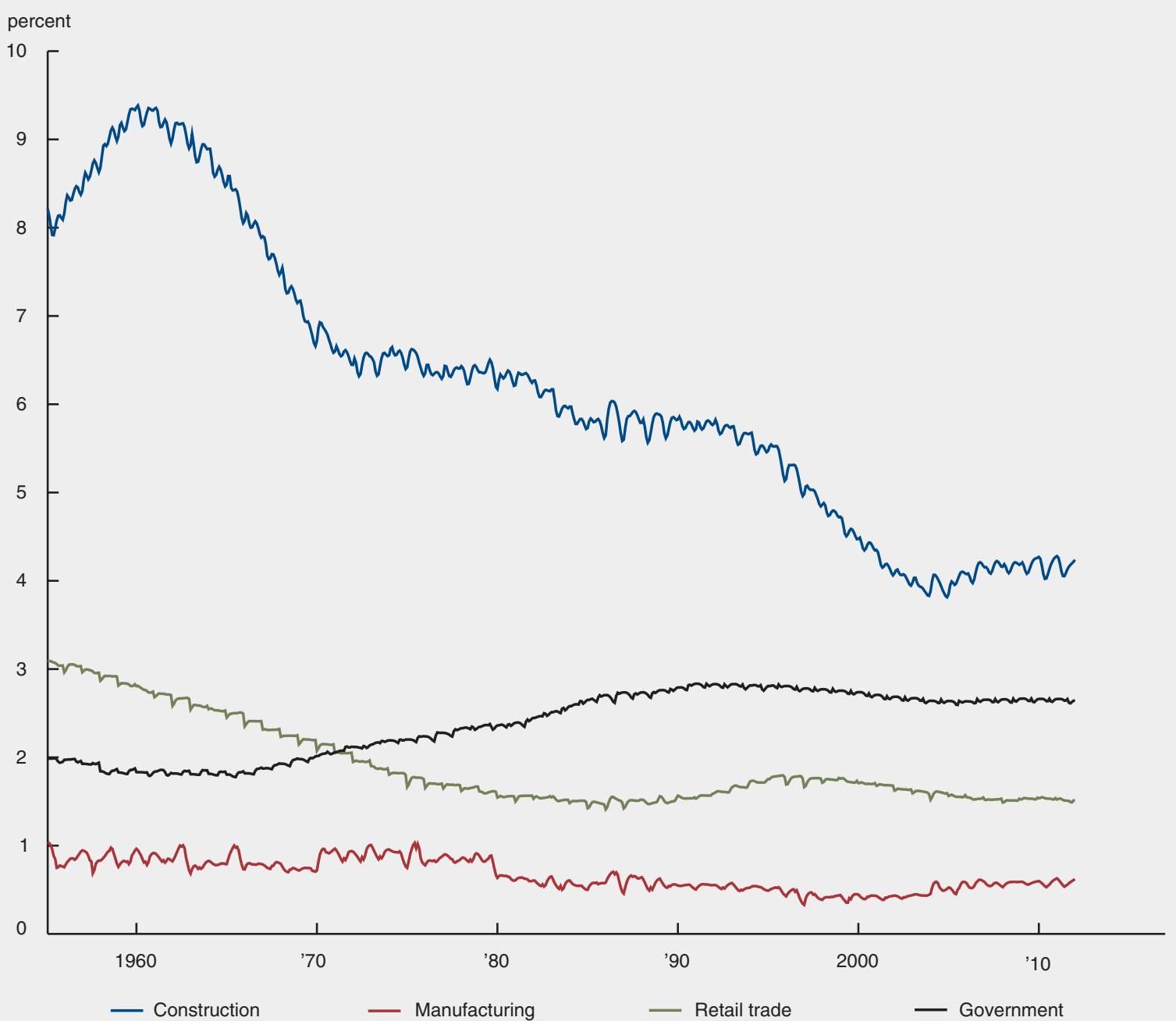

Notes: The figure depicts, for four industries, the standard deviation of the estimated monthly dummy coefficients from equation 2 (that is, Seas) using ten-year rolling windows. See the text for further details.

Source: Authors' calculations based on data from the U.S. Bureau of Labor Statistics, Current Employment Statistics, from Haver Analytics.

The median (mean) seasonality falls from 1.48 percent (2.04 percent) to 1.03 percent ( 1.10 percent). Hence, the decline is very broad-based. The decline is not the result of a compositional change where economic activity has moved to the southern (less seasonal) states.

\section{Are seasonal industries and states also more sensitive to the business cycle?}

We now turn to our second topic: Is there a relationship between seasonality and business cyclicalitythat is, are industries or states that are more seasonal also more sensitive to the business cycle? We start by describing our theoretical motivation, before constructing a simple measure of cyclicality. Finally, we study the link between our measure of seasonality (defined in the previous section) and our measure of cyclicality, using both simple graphical analysis and quantitative statistical methods. 
Rolling measure of employment seasonality for selected states, 1956-2016

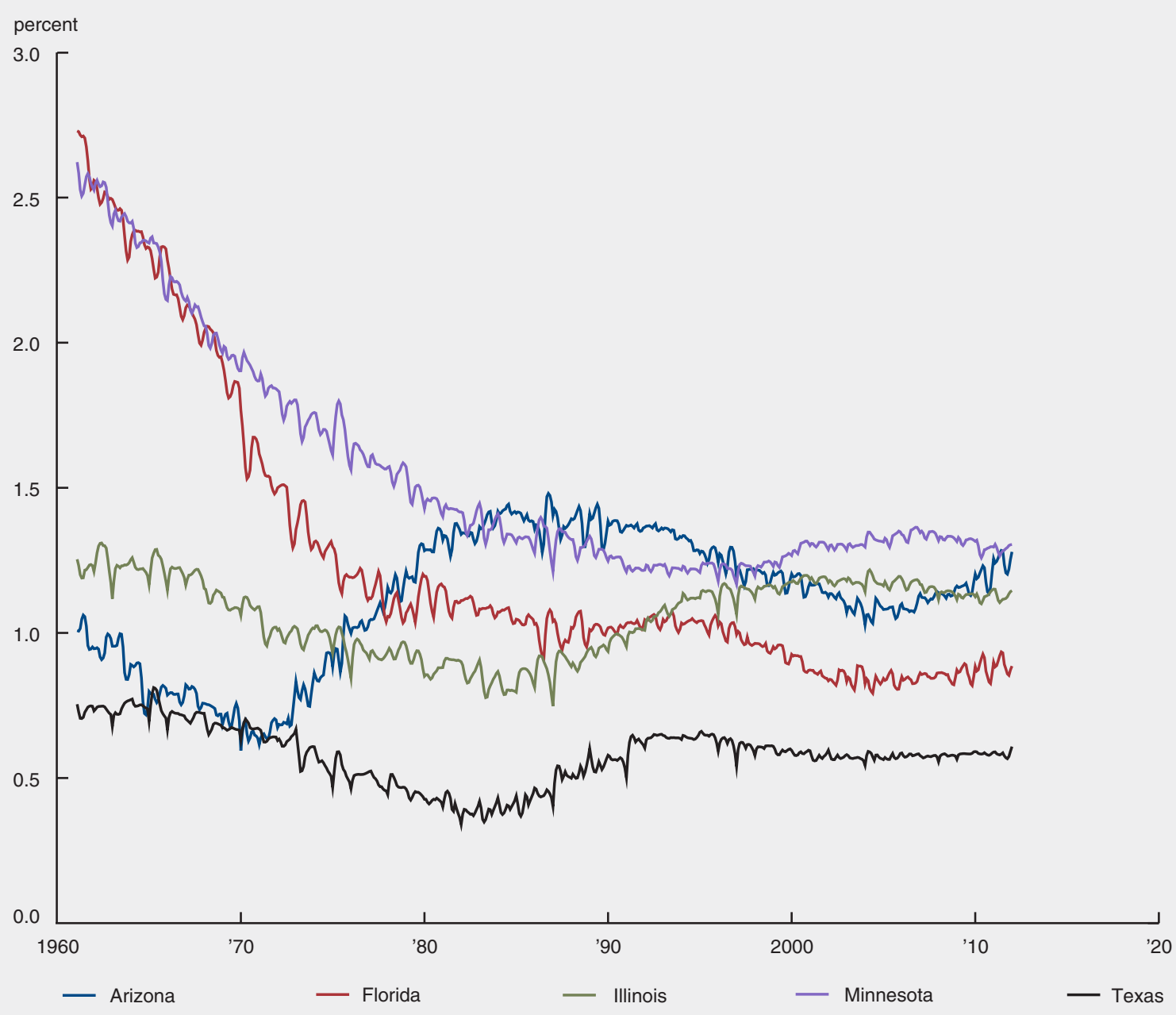

Notes: The figure depicts, for five selected states, the standard deviation of the estimated monthly dummy coefficients from equation 3 (that is, Seas ${ }_{i s}$ ) using ten-year rolling windows. See the text for further details. Source: Authors' calculations based on data from the U.S. Bureau of Labor Statistics, Current Employment Statistics, from Haver Analytics.

\section{Theoretical motivation}

Some authors have argued on theoretical and empirical grounds that seasonality and business cyclicality are related. One plausible mechanism is that higher seasonality leads firms to become more flexible, which in turn makes them more reactive to business cycle shocks. This theory would imply that more seasonal sectors are also more cyclical. A different argument is that more-seasonal sectors are more likely to face certain constraints that might make them less cyclical. For instance, in a very seasonal state, the impact of a business cycle shock on construction might be limited due to technological constraints during the winter or due to capacity constraints in the summer. This would suggest that high-seasonality sectors are less cyclical. Overall, Beaulieu, MacKie-Mason, and Miron (1992) report evidence in favor of a positive relationship between seasonality and cyclicality, consistent with the former hypothesis. We want to revisit this work for two reasons. First, we are interested to see if these results hold when more-recent data, including those from the Great Recession years, are incorporated. Second, one criticism of some of this 


\begin{tabular}{|c|c|c|c|}
\hline \multicolumn{4}{|c|}{ TABLE 4} \\
\hline \multicolumn{4}{|c|}{ Rolling measure of employment seasonality, by industry } \\
\hline Industry & Seasonality in 1960 & Seasonality in 2010 & Change \\
\hline & \multicolumn{2}{|c|}{ (- - - - - - - - percent - - - - - - - -) } & (percentage points) \\
\hline Construction & 9.38 & 4.25 & -5.14 \\
\hline Mining & 1.73 & 1.50 & -0.23 \\
\hline Manufacturing & 0.95 & 0.59 & -0.36 \\
\hline Education & 1.10 & 1.00 & -0.10 \\
\hline Finance & 0.81 & 0.48 & -0.33 \\
\hline Information & 0.94 & 0.43 & -0.51 \\
\hline Leisure & 2.38 & 3.31 & 0.93 \\
\hline Professional and business services & 0.98 & 1.00 & 0.02 \\
\hline Retail trade & 2.81 & 1.54 & -1.27 \\
\hline Other services & 1.08 & 0.77 & -0.31 \\
\hline Transportation and utilities & 1.06 & 0.97 & -0.09 \\
\hline Wholesale & 0.97 & 0.51 & -0.46 \\
\hline Government & 1.83 & 2.66 & 0.83 \\
\hline Total & 1.24 & 0.77 & -0.47 \\
\hline \multicolumn{4}{|c|}{$\begin{array}{l}\text { Notes: Seasonality }\left(\text { Seas }_{j} \text { ) is defined as the standard deviation of the estimated monthly dummy coefficients from equation } 2\right. \\
\text { for each industry. The table reports the seasonality in } 1960 \text { (estimated over the period 1956-65), the seasonality in } 2010 \\
\text { (estimated over the period } 2006-15 \text { ), and the difference between them. The values in the final column may not equal the } \\
\text { differences between the values in the previous two columns because of rounding. See the text for further details. }\end{array}$} \\
\hline \multicolumn{4}{|c|}{$\begin{array}{l}\text { Source: Authors' calculations based on data from the U.S. Bureau of Labor Statistics, Current Employment Statistics, from } \\
\text { Haver Analytics. }\end{array}$} \\
\hline
\end{tabular}

18 work is that it does not address well why seasonality is different across industries or states. In particular, is it because demand or supply is more seasonal? We propose exploiting the heterogeneity across states in seasonality to address this second concern. At least for construction, it is clearly driven by the seasonality of supply being larger in some states because of weather conditions. ${ }^{14}$

\section{Measuring business cyclicality}

In order to systematically measure cyclicality—which here we define as the degree of responsiveness of an industry's employment to business cycle fluctuations - we estimate separately the following linear regression for each industry:

4) $y_{i t}=\sum_{k=1}^{12} \beta_{i k} D_{k}+\gamma_{i} Y_{N, t}+\varepsilon_{i t}$,

where $y_{i t}$ is HP-filtered log employment (nonseasonally adjusted) of industry $i$ at time $t ; \beta_{i k}$ is a dummy coefficient for industry $i$ in month $k ; D_{k}$ is a monthly dummy for month $k ; \gamma_{i}$ is the cyclicality coefficient for industry $i ; Y_{N, t}$ is national employment; and $\varepsilon_{i t}$ is an error term. 


\section{Cyclicality of employment in industries, 1990-2016}

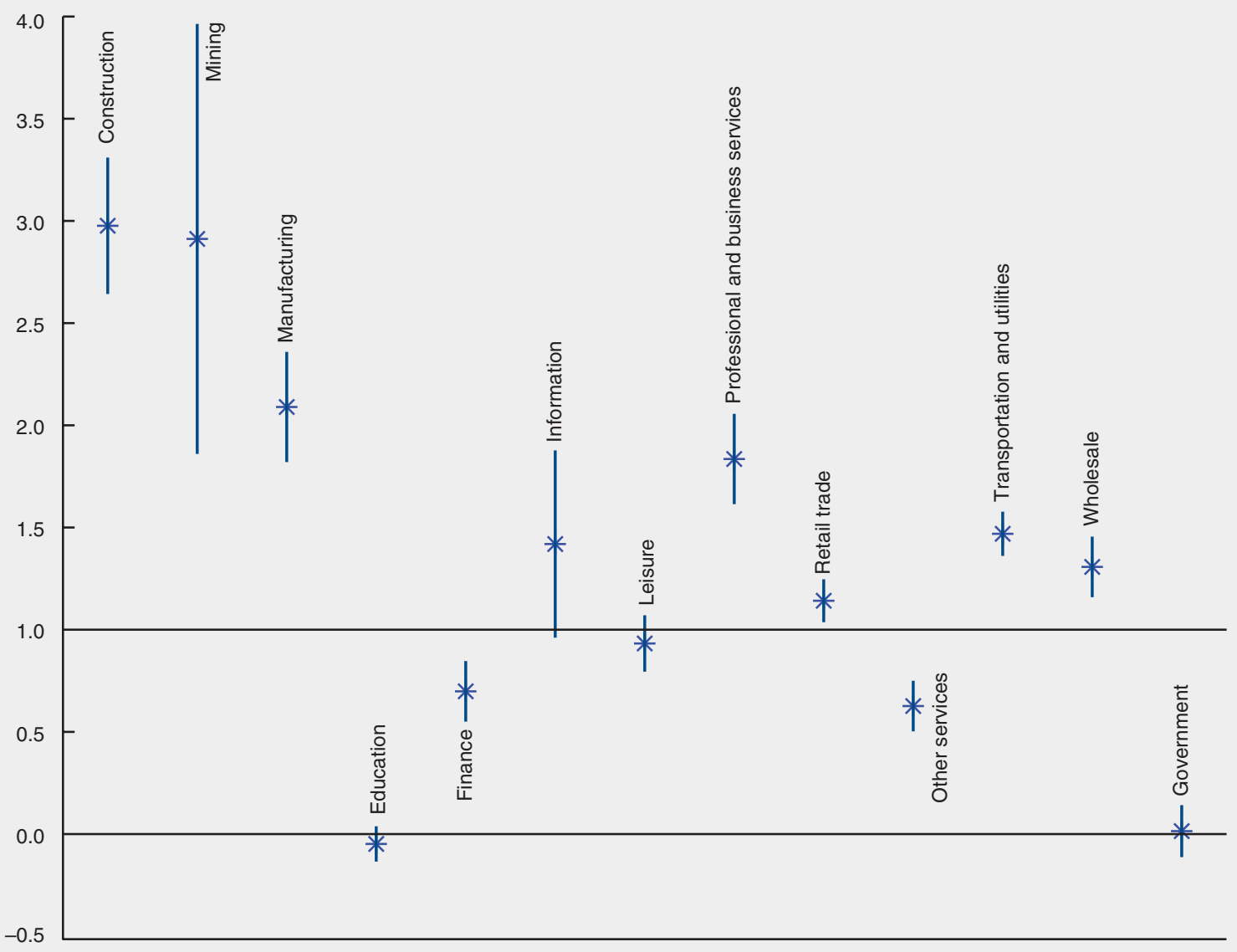

Notes: The figure plots the point estimates of the cyclicality coefficients $\left(\gamma_{i}\right)$ from equation 4 (asterisks) for employment in 13 industries, together with plus and minus two-standard-error bands (vertical lines that run through the asterisks). See the text for further details.

Source: Authors' calculations based on data from the U.S. Bureau of Labor Statistics, Current Employment Statistics, from Haver Analytics.

We estimate separately the following similar linear regression for each industry in each state as well:

5) $y_{i s t}=\sum_{k=1}^{12} \beta_{i s k} D_{k}+\gamma_{i s} Y_{N, t}+\varepsilon_{i s t}$,

where $y_{i s t}$ is HP-filtered log employment (nonseasonally adjusted) of industry $i$ in state $s$ at time $t ; \beta_{i s k}$ is a dummy coefficient for industry $i$ in state $s$ and month $k ; D_{k}$ is a monthly dummy for month $k ; \gamma_{i s}$ is the cyclicality coefficient for industry $i$ in state $s ; Y_{N, t}$ is national employment; and $\varepsilon_{i s t}$ is an error term. We use national employment as a measure of the business cycle on the right-hand side in both equations. We do so because employment is one of the most cyclical macroeconomic variables; its volatility is similar to that of real gross domestic product (GDP) over the past 30 years, and it is a nearly coincident indicator of business cycles. Indeed, national employment is one of the key series that the NBER uses in determining the dates of cyclical peaks and troughs. Using employment on both the left-hand and right-hand sides of the equations also allows for a simple interpretation of the coefficient $\gamma_{i}$ (or $\left.\gamma_{i s}\right)$ as the exposure of a sector to the business cycle - for instance, if $\gamma_{i}=1$, the industry's employment moves one-for-one with aggregate employment. We add monthly dummies on the right-hand side because all our data are nonseasonally adjusted. ${ }^{15}$ 


\section{Cyclicality of construction employment in states, 1990-2016}

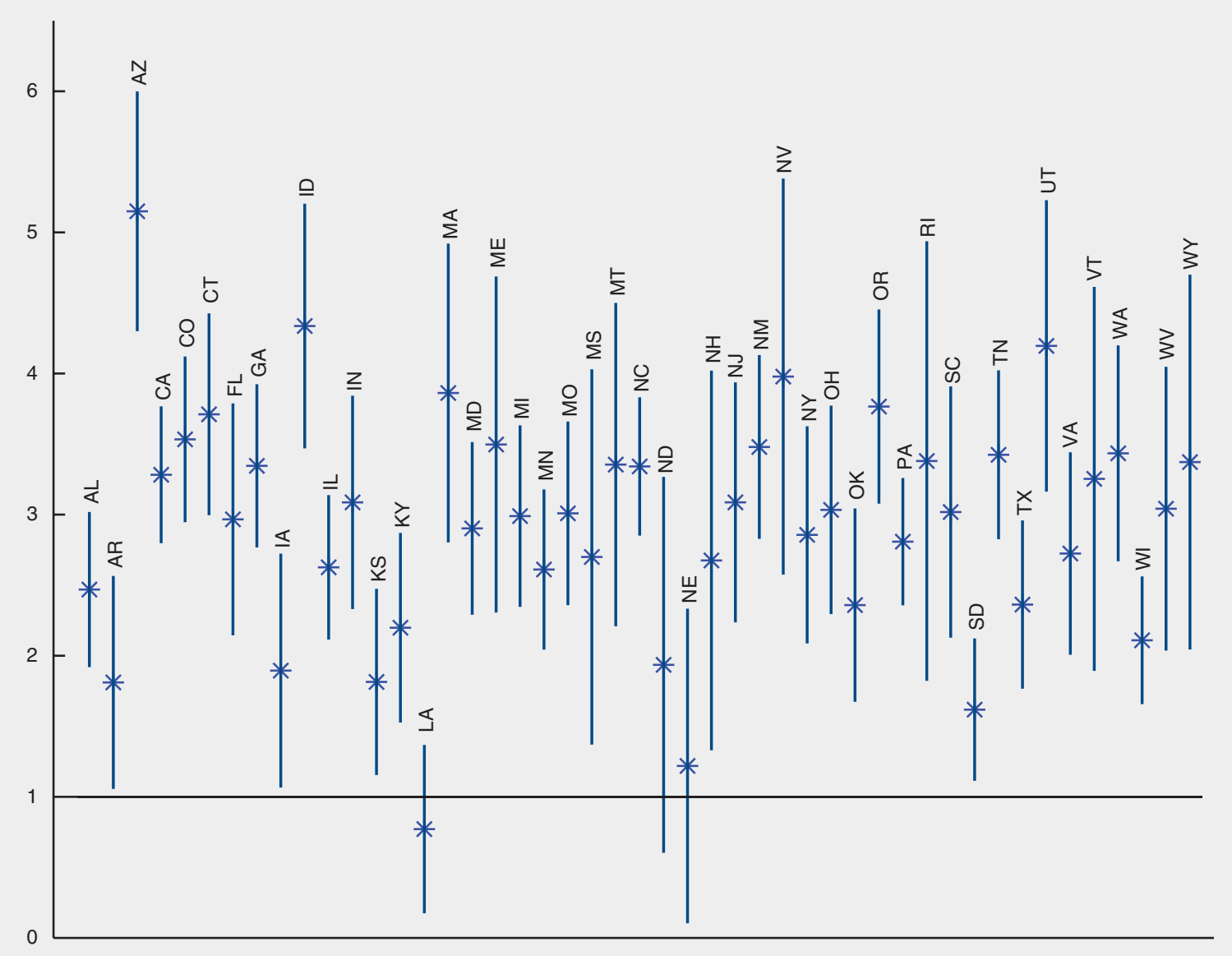

Notes: The figure plots the point estimates of the cyclicality coefficients $\left(\gamma_{i s}\right)$ from equation 5 (asterisks) for construction employment in 47 states, together with plus and minus two-standard-error bands (vertical lines that run through the asterisks). See the text for further details.

Source: Authors' calculations based on data from the U.S. Bureau of Labor Statistics, Current Employment Statistics, from Haver Analytics.

Figure 15 presents the point estimates of the cyclicality coefficients $\left(\gamma_{i}\right)$ for employment, together with the plus and minus two-standard-error confidence bands, for each industry. The figure confirms the well-known fact that industries differ significantly in their exposures to the U.S. business cycle. Specifically, most industries (such as finance, leisure, retail trade, other services, and wholesale) have a cyclicality close to 1. However, construction and mining both have a cyclicality of around 3; manufacturing and professional and business services both have a cyclicality close to 2; and information services and transportation and utilities both have a cyclicality of around 1.5. The least cyclical industries are education and governmentboth with a cyclicality not significantly different from zero. ${ }^{16}$

Less well known is whether there is significant heterogeneity across U.S. states in their exposure to the business cycle. To control for differences in industry composition, we focus in figure 16 on the construction industry - and in figure 17 on manufacturing — and report the cyclicality coefficients from equation 5 for this industry in all 47 states in our sample. Overall, the similarity of the cyclicality of an industry's employment across states is striking. For construction, most states have a cyclicality of around 3, and for manufacturing most states have a cyclicality close to 2 . The few outliers in figures 16 and 17 are fairly easy to 


\section{Cyclicality of manufacturing employment in states, 1990-2016}

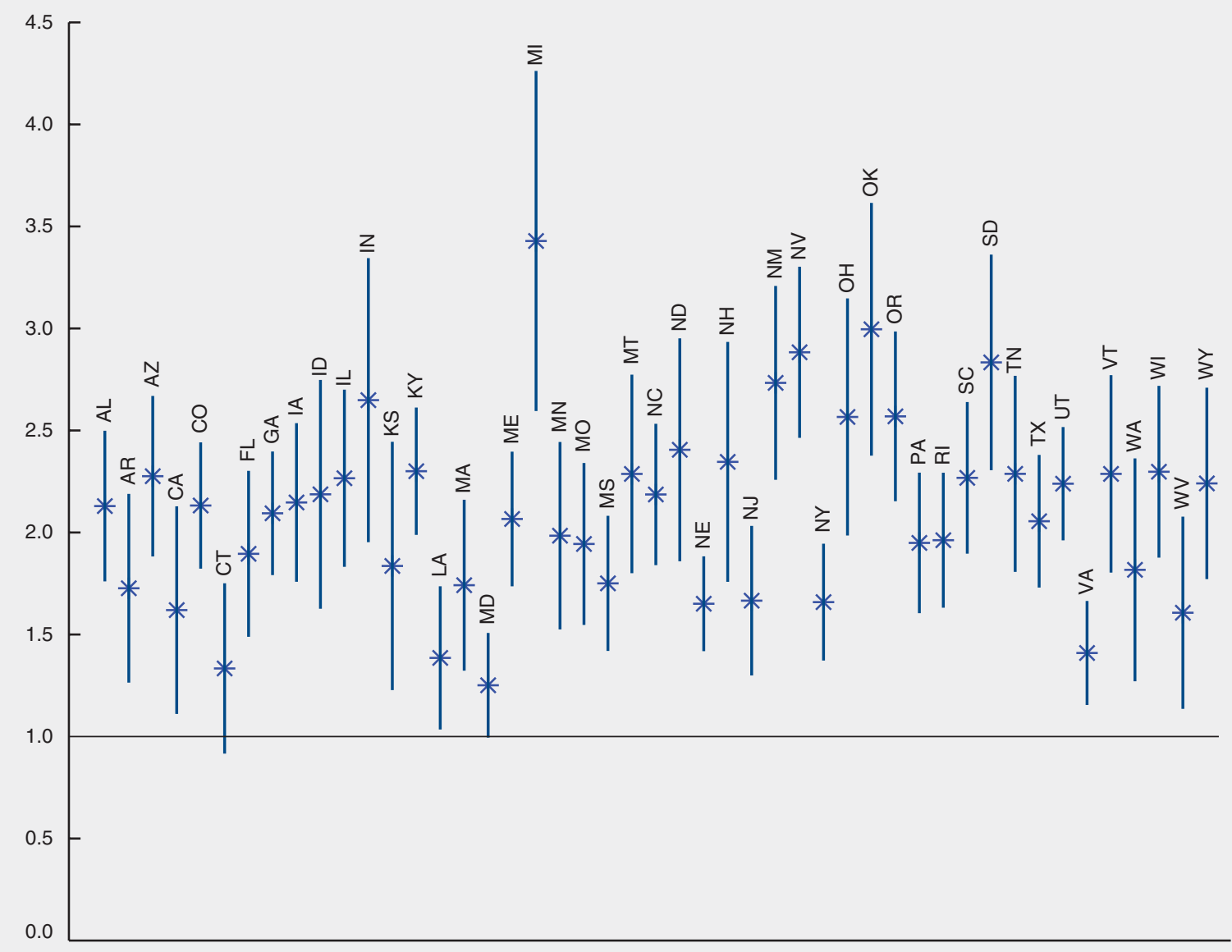

Notes: The figure plots the point estimates of the cyclicality coefficients $\left(\gamma_{i s}\right)$ from equation 5 (asterisks) for manufacturing employment in 47 states, together with plus and minus two-standard-error bands (vertical lines that run through the asterisks). See the text for further details.

Source: Authors' calculations based on data from the U.S. Bureau of Labor Statistics, Current Employment Statistics, from Haver Analytics.

understand: Arizona went through a large housing boom-and-bust cycle; Louisiana had a huge economic shock in August 2005 from Hurricane Katrina, which dramatically changed the construction industry there, affecting the estimate of cyclicality; and Michigan's manufacturing is specialized in cars, whose production is more cyclically sensitive. Table 2 reports for each industry the standard deviation (across states) of cyclicality (second column of data), which is small for most industries (for instance, relative to the typical cyclicality, reported in the final column of table 1). This confirms the graphical findings of figures 16 and 17.

\section{Relationship between seasonality and business cyclicality: Graphical analysis}

To investigate the relationship between the seasonality and business cyclicality of employment, we first present some simple figures, and we start by focusing on the 13 industries at the national level, using our longest data sample (1939-2016). Figure 18 plots the cyclicality coefficients against our measure of seasonality. A clear outlier is construction, which is both the most cyclical and the most seasonal industry. Apart from construction, however, there is no clear correlation. For instance, manufacturing is very cyclical, but not strongly seasonal, while retail trade, leisure, and government are more seasonal than average, but not 
Seasonality versus cyclicality of employment in industries, 1939-2016

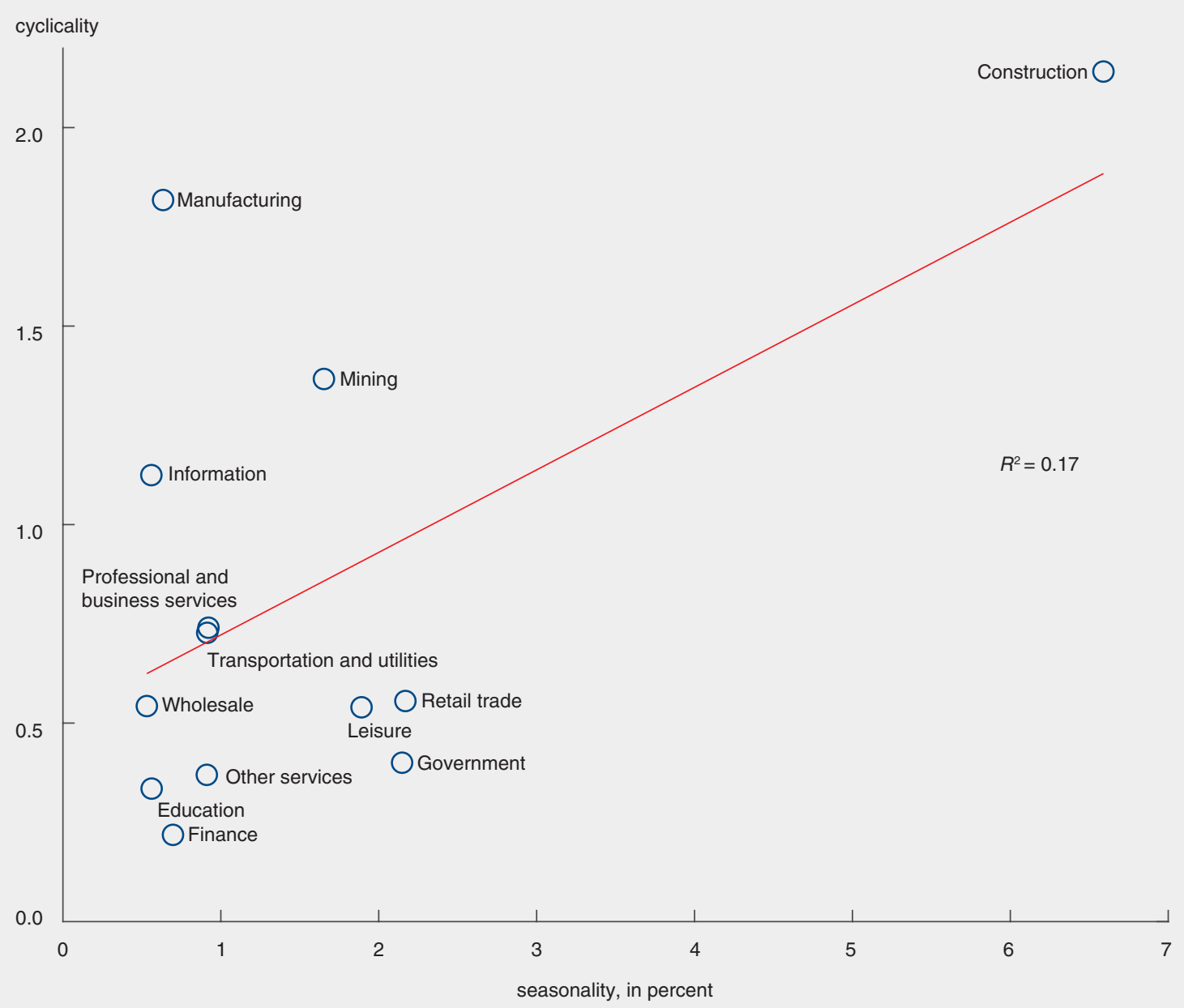

Notes: The figure plots the seasonality coefficient Seas, (the standard deviation of estimated monthly dummies from equation 2) against the cyclicality coefficient $\gamma_{i}$ (estimated from equation 4 ) for each of the 13 industries. The red line is a linear regression fit. See the text for further details.

Source: Authors' calculations based on data from the U.S. Bureau of Labor Statistics, Current Employment Statistics, from Haver Analytics.

especially cyclical. Overall, it is difficult to draw a clear conclusion because the correlation is weak and sensitive to the one outlier. The construction industry is special in many ways - it produces a highly durable asset, and it faces specific technological constraints. This industry's particular characteristics motivate us to study the relationship between the seasonality and cyclicality of employment across U.S. states within a single industry in order to control for industry characteristics.

Figures 19 and 20 depict the seasonality and cyclicality of employment across states for the construction and manufacturing industries, respectively. In figure 19, we find a very weak negative correlation between seasonality and cyclicality across states. This is in contrast to the result of figure 18 . However, we find the result of figure 19 to be more convincing because the variation of seasonality across states is driven by variation in average temperature as shown in figure 6 . This climate difference generates a plausibly exogenous variation in seasonality. Interestingly, for the manufacturing industry, we observe in figure 20 a positive correlation between seasonality and cyclicality, rather than the very weak negative one we see for construction. To complement 
Seasonality versus cyclicality of construction employment in states, 1990-2016 cyclicality

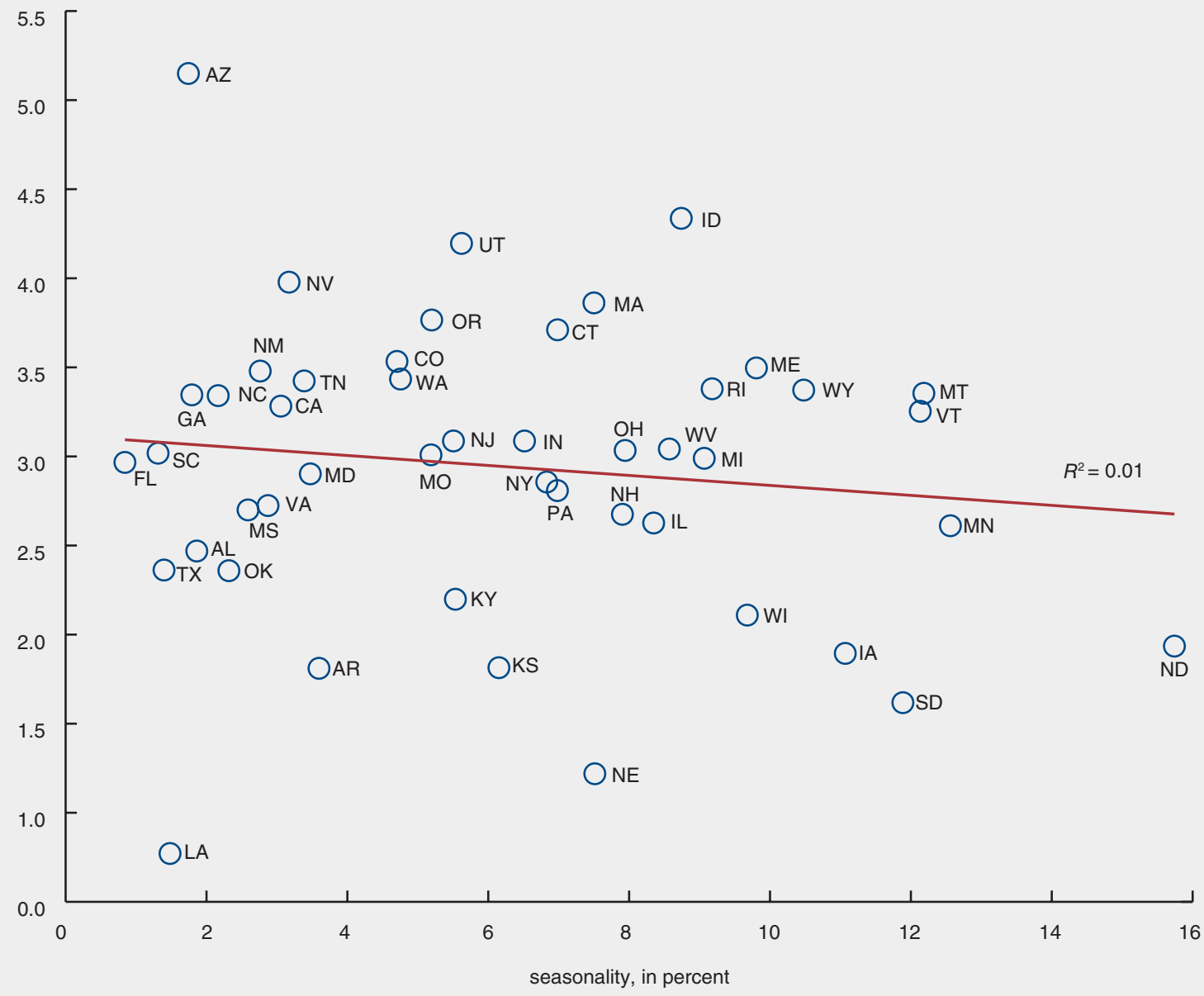

Notes: The figure plots the seasonality coefficient Seas (the standard deviation of estimated monthly dummies from equation 3 ) against the cyclicality coefficient $\gamma_{\text {is }}$ (estimated from equation 5 ) for the construction industry in each of the 47 states. The red line is a linear regression fit. See the text for further details.

Source: Authors' calculations based on data from the U.S. Bureau of Labor Statistics, Current Employment Statistics, from Haver Analytics.

figures 19 and 20, we report in the final column of table 2 the correlation (across states) between seasonality and cyclicality for each industry. This correlation is weak for most industries; moreover, the sign varies across industries. These results suggest either that the relationship between seasonality and cyclicality is industry-dependent or that it may be weak overall.

\section{Relationship between seasonality and business cyclicality: Econometric analysis}

To quantify the graphical results of the previous section in a more rigorous fashion, we estimate the following linear regression model separately for each industry:

6) $y_{i s t}=\sum_{k=1}^{12} \sum_{s=1}^{47} \beta_{i s k} D_{k} D_{s}+\left(\delta_{0, i}+\delta_{1, i} \operatorname{Seas}_{i s}\right) Y_{N, t}+\varepsilon_{i s t}$,

where $y_{i s t}$ is HP-filtered $\log$ employment (nonseasonally adjusted) of industry $i$ in state $s$ at time $t$; $\beta_{i s k}$ is 


\section{Seasonality versus cyclicality of manufacturing employment in states, 1990-2016}

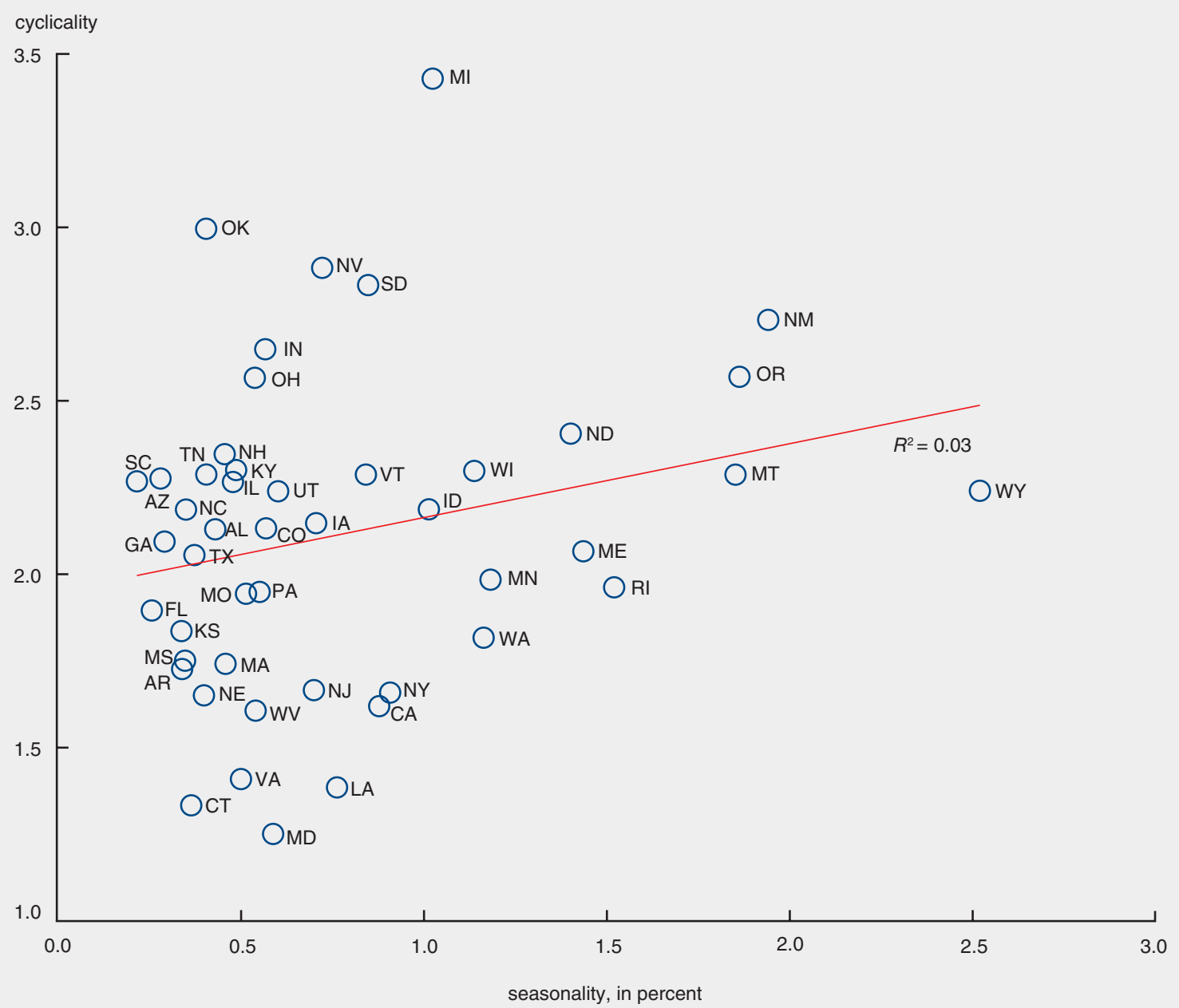

Notes: The figure plots the seasonality coefficient Seas (the standard deviation of estimated monthly dummies from equation 3) against the cyclicality coefficient $\gamma_{i s}$ (estimated from equation 5) for the manufacturing industry in each of the 47 states. The red line is a linear regression fit. See the text for further details.

Source: Authors' calculations based on data from the U.S. Bureau of Labor Statistics, Current Employment Statistics, from Haver Analytics.

the monthly dummy coefficient for industry $i$ in state $s$ and month $k ; D_{k}$ and $D_{s}$ are monthly and state dummies, respectively; $\delta_{0, i}$ is a baseline industry cyclicality coefficient; $\delta_{1, i}$ is the coefficient measuring the interaction between seasonality and cyclicality; $\operatorname{Seas}_{i s}$ is the seasonality coefficient of industry $i$ in state $s$ (itself estimated as the standard deviation of the estimated monthly dummies for each state-industry series); $Y_{N, t}$ is national employment; and $\varepsilon_{i s t}$ is an error term. Note that for each industry, this equation is estimated over a panel of state-time observations, from 1990 through $2016 .{ }^{17}$

The logic of this regression is that we want to measure directly if the cyclicality of employment is higher in industries with more-seasonal employment using the interaction term $\delta_{1, i}$. A positive (negative) $\delta_{1, i}$ reflects that higher seasonality is associated with more (less) cyclicality. Unlike what we did for the graphical analysis, we restrict the dependence of the cyclicality coefficient on seasonality in order to improve statistical precision. ${ }^{18}$ However, we allow for full flexibility in the monthly dummies to allow seasonality patterns to be different across states for each industry. 
TABLE 5

Seasonality and cyclicality of employment, by industry, 1990-2016

\begin{tabular}{|c|c|c|c|c|c|c|c|}
\hline Industry & $\delta_{0, i}$ & $\begin{array}{l}\text { Standard } \\
\text { error }\end{array}$ & $\delta_{1, i}$ & $\begin{array}{c}\text { Standard } \\
\text { error }\end{array}$ & $\begin{array}{c}\text { Number of } \\
\text { observations }\end{array}$ & R-squared & $\begin{array}{c}\text { One- } \\
\text { standard- } \\
\text { deviation } \\
\text { effect }\end{array}$ \\
\hline Construction & $3.117^{* * *}$ & $(0.270)$ & -2.799 & (3.620) & 15,228 & 0.905 & -0.103 \\
\hline Mining & $2.331^{\star * *}$ & (0.339) & 4.653 & $(6.676)$ & 15,228 & 0.652 & 0.189 \\
\hline Manufacturing & $1.950 * * *$ & $(0.110)$ & $21.299^{\star *}$ & (8.621) & 15,228 & 0.711 & 0.110 \\
\hline Education & 0.016 & $(0.044)$ & $-5.351^{*}$ & $(2.915)$ & 15,228 & 0.717 & -0.027 \\
\hline Finance & $0.747^{\star \star *}$ & $(0.126)$ & -23.704 & (16.303) & 15,228 & 0.449 & -0.052 \\
\hline Information & $1.237^{\star \star \star}$ & (0.299) & 9.554 & $(48.764)$ & 15,228 & 0.258 & 0.022 \\
\hline Leisure & $1.017^{\star \star *}$ & $(0.101)$ & -1.807 & (1.685) & 15,228 & 0.959 & -0.051 \\
\hline \multicolumn{8}{|l|}{$\begin{array}{l}\text { Professional } \\
\text { and business }\end{array}$} \\
\hline Retail trade & $0.676^{\star * *}$ & $(0.178)$ & $19.076^{* *}$ & $(7.722)$ & 15,228 & 0.891 & 0.074 \\
\hline Other services & $0.472^{\star \star \star}$ & $(0.124)$ & 12.634 & (10.788) & 15,228 & 0.457 & 0.075 \\
\hline \multicolumn{6}{|l|}{ Transportation } & 0.632 & -0.071 \\
\hline Wholesale & $1.655^{\star \star \star}$ & $(0.103)$ & $-53.542^{* \star \star}$ & (11.748) & 15,228 & 0.628 & -0.169 \\
\hline Government & -0.039 & $(0.079)$ & 0.776 & $(1.815)$ & 15,228 & 0.928 & 0.011 \\
\hline Total & $1.062^{* * *}$ & $(0.098)$ & -5.208 & (7.956) & 15,228 & 0.893 & -0.021 \\
\hline $\begin{array}{l}{ }^{*} \text { Significant at } \\
{ }^{\star *} \text { Significant at } \\
\text { ** Significant at }\end{array}$ & $\begin{array}{l}\text { percent level } \\
\text { oercent level. } \\
\text { oercent level. }\end{array}$ & & & & & & \\
\hline \multicolumn{8}{|c|}{$\begin{array}{l}\text { Notes: The table presents the coefficient estimates }\left(\delta_{0, i} \text { coefficients measure the baseline cyclicality for a hypothetical state }\right. \\
\text { with zero seasonality, and } \delta_{1,} \text { coefficients measure the interaction between seasonality and cyclicality), standard errors, } \\
\text { number of observations, R-squared values, and the effects of a one-standard-deviation change in seasonality on cyclicality } \\
\text { based on the panel regressions of equation } 6 \text {. See the text for further details. }\end{array}$} \\
\hline \multicolumn{8}{|c|}{$\begin{array}{l}\text { Source: Authors' calculations based on data from the U.S. Bureau of Labor Statistics, Current Employment Statistics, from } \\
\text { Haver Analytics. }\end{array}$} \\
\hline
\end{tabular}

The regression results from equation 6 are presented in table 5 . The $\delta_{0, i}$ coefficients in the first column of data, which measure the baseline cyclicality (for a hypothetical state with zero seasonality), are fairly similar to those estimated previously (see figure 15 and the final column in table 1). They are statistically significant at the 1 percent level for all industries except for education and government. The $\delta_{1, i}$ coefficients in the third column of data, which measure the interaction between seasonality and cyclicality, are significant at the 1 percent level for wholesale, at the 5 percent level for retail trade and manufacturing, and at the 10 percent level for education and transportation and utilities.

The sign of the $\delta_{1, i}$ coefficients varies across industries as well. For construction, education, finance, leisure, transportation and utilities, and wholesale, higher seasonality is associated with lower cyclicality. In contrast, for mining, manufacturing, information, professional and business services, retail trade, other services, and government, higher seasonality is associated with higher cyclicality.

However, the magnitudes of these associations are not very large. The final column of table 5 reports the change in the cyclicality coefficient if the seasonality of employment is one standard deviation (across 
states) higher. For construction, a one-standard-deviation increase in seasonality reduces cyclicality only by about 0.10 . This must be compared with the baseline cyclicality of 3.12 for a state with zero seasonality. Hence, a state with a seasonality one standard deviation higher would have a cyclicality equal to about 3.02. The entire range of seasonality across states is about three standard deviations, so the difference in cyclicality between the highest- and lowest-seasonality states is about 0.3 (or a 10 percent difference). The feature of the data driving our results is simple: As noted in figures 9 and 16, the seasonality of construction employment across states is very different, but the cyclicality of construction employment across them is rather similar. It is not too surprising then that seasonality has at most a weak association with cyclicality.

The magnitudes of the one-standard-deviation associations, reported in the last column of table 5, are somewhat higher for other industries. For instance, for wholesale, the baseline cyclicality is 1.66 and a one-standard-deviation change in seasonality moves this coefficient by 0.17 . The fact that the sign of the association varies across industries suggests that the mechanisms that generate this association may vary across industries as well. A more negative view is that there is no systematic relationship between cyclicality and seasonality. Hence, our results stand in contrast to those of Beaulieu, MacKie-Mason, and Miron (1992). ${ }^{19}$

\section{Conclusion}

U.S. employment exhibits significant seasonality. The amplitude of the seasonal variation declined between the 1960s and the mid-1980s and has remained relatively stable since. The amplitude and timing patterns of the seasonal variation in employment differ across industries and also across states for a particular industry. We exploit this heterogeneity to study the relationship between seasonality and business cyclicality, and find overall little association between the two: While sometimes statistically significant, the association is fairly modest in magnitude.

There are several interesting future directions for research. Our study was limited to employment, but one could consider a broader set of economic series, including production and sales (though these are not as readily available at a finely disaggregated level). One could also study countries other than the United States. Finally, one important direction for future research is to determine which factors drove the decline in the seasonality of employment from the 1960 s to the mid-1980s.

\section{NOTES}

${ }^{1}$ One example of such a procedure is X-13, which is used by the U.S. Census Bureau; see, for instance, Wright (2013) for a description.

2Indeed, one of the purposes of the creation of the Federal Reserve in December 1913 was to provide an "elastic currency" that could be used to facilitate this seasonal borrowing. See, for instance, Veracierto (2005).

${ }^{3}$ More precisely, the CES reports the number of people on the payroll during the pay period that includes the reference week. Further details about CES data collection are available online, https:/www.bls.gov/web/empsit/cesfaq.htm\#DataCollection.

${ }^{4}$ The 13 industries - based on categories from the North American Industry Classification System (NAICS) - are as follows: construction, mining, manufacturing, education, finance, information, leisure, professional and business services, retail trade, wholesale, transportation and utilities, other (private sector) services, and government.

${ }^{5}$ We exclude Hawaii, Delaware, and the District of Columbia because of the lack of data for some industries during our sample periods. We also exclude Alaska because it has an extreme seasonal cycle, though our results hold when we include it.

${ }^{6}$ The Hodrick-Prescott filter is a statistical technique that removes a smooth trend from a time series. We use a value of 14,400 for the smoothing parameter as is standard for monthly data.

${ }^{7}$ To correct for serial correlation in the residual, we estimate the standard errors using the Newey-West formula (Newey and West, 1987). 
${ }^{8}$ Figure 2 also shows positive spikes in government employment in 1990, 2000, and 2010, which are due to short-term hiring increases to conduct the decennial U.S. Census.

${ }^{9}$ In some cases, the two-standard-error bands are not clearly visible because they are quite small. Note also the different vertical axis scales of the different panels of figure 3 .

${ }^{10} \mathrm{All}$ industries have statistically significant seasonality, in the sense that the monthly dummies are jointly statistically significant. An $F$ test that the monthly effects (or monthly dummy coefficients) are all equal is rejected at $p<1$ percent for all industries.

${ }^{11}$ Here, seasonality $\left(\right.$ Seas $\left._{i s}\right)$ is defined as the standard deviation of the monthly dummy coefficients from equation 3 ; formally, Seas $_{i s}=\sqrt{\frac{1}{12} \sum_{k=1}^{12} \beta_{i s k}^{2}}$. This measure of seasonality is similar to the one explained in the text, but applied to each industry in each state rather than to each industry nationally.

${ }^{12}$ The couriers and messengers industry includes companies such as UPS and FedEx. Formally, according to the North American Industry Classification System, this industry (code 492) is defined as the subsector of transportation providing "intercity, local, and/or international delivery of parcels and documents (including express delivery services) without operating under a universal service obligation," and notably, "these articles may originate in the U.S. but be delivered to another country and can be described as those that may be handled by one person without using special equipment" (Executive Office of the President, Office of Management and Budget, 2017, p. 404). The negative spike in 1997 is due to a strike.

${ }^{13}$ The only previous reference we find documenting this fact is Rydzewski, Deming, and Rones (1993).

${ }^{14} \mathrm{~A}$ related but separate question is whether there are interactions between seasonality patterns and the business cycle. In particular, are the effects of a business cycle shock different if it hits at a seasonal peak or trough? This interaction is neither sufficient nor necessary for there to exist a relationship between seasonality and cyclicality. For more on this topic, see Krane and Wascher (1999), Matas-Mir and Osborn (2004), Cecchetti and Kashyap (1996), and Cecchetti, Kashyap, and Wilcox (1997).

${ }^{15}$ Standard linear regressions results (for instance, the Frisch-Waugh theorem) imply that the estimated cyclicality coefficients $\left(\gamma_{i}\right)$ are identical if we run $y_{i t}$ (nonseasonally adjusted industry employment) on seasonally adjusted national employment rather than on nonseasonally adjusted national employment (under the assumption that seasonal adjustment is equivalent to regressing on monthly dummies). The estimated cyclicality coefficients $\left(\gamma_{i}\right)$ are also very similar if instead we use seasonally adjusted data on both sides of an equation and remove the monthly dummies from equation 4 (or equation 5).

${ }^{16}$ These results are based on the 1990-2016 sample; they are broadly similar if one extends the data back to 1939 (see table 1 for these estimates). The cyclicality values for both construction and finance employment are somewhat smaller when the 1939-2016 sample is used because in our shorter sample the large housing boom-and-bust cycle of the 2000s plays a more important role.

${ }^{17}$ The standard errors for this model are obtained by double-clustering across states and time.

${ }^{18}$ In the graphical analysis, we estimate a separate cyclicality coefficient for each state-industry series, leading us to estimate more parameters.

${ }^{19} \mathrm{An}$ important difference between Beaulieu, MacKie-Mason, and Miron (1992) and our article is that these authors define business cyclicality somewhat differently. Cyclicality is defined in their article as nonseasonal volatility, that is, the volatility of the residual $\varepsilon_{i s t}$ in equation 3 , whereas we define cyclicality as the coefficient $\gamma_{i s}$ from equation 5.

REFERENCES

Barsky, Robert B., and Jeffrey A. Miron, 1989, “The seasonal cycle and the business cycle," Journal of Political Economy, Vol. 97, No. 3, June, pp. 503-534. Crossref, https://doi.org/10.1086/261614

Beaulieu, J. Joseph, Jeffrey K. MacKie-Mason, and Jeffrey A. Miron, 1992, "Why do countries and industries with large seasonal cycles also have large business cycles?," Quarterly Journal of Economics, Vol. 107, No. 2, May, pp. 621-656. Crossref, https://doi.org/10.2307/2118484

Cecchetti, Stephen G., and Anil K Kashyap, 1996, “International cycles,” European Economic Review, Vol. 40, No. 2, February, pp. 331-360. Crossref, https://doi.org/10.1016/0014-2921(95)00125-5 
Cecchetti, Stephen G., Anil K Kashyap, and David W. Wilcox, 1997, "Interactions between the seasonal and business cycles in production and inventories," American Economic Review, Vol. 87, No. 5, December, pp. 884-892.

Executive Office of the President, Office of Management and Budget, 2017, North American Industry Classification System: United States, 2017, Washington, DC, available online, https://www.census.gov/ eos/www/naics/2017NAICS/2017_NAICS_Manual.pdf.

Krane, Spencer, and William Wascher, 1999, "The cyclical sensitivity of seasonality in U.S. employment," Journal of Monetary Economics, Vol. 44, No. 3, December, pp. 523-553. Crossref, https://doi.org/10.1016/ S0304-3932(99)00036-7

Matas-Mir, Antonio, and Denise R. Osborn, 2004, "Does seasonality change over the business cycle? An investigation using monthly industrial production series," European Economic Review, Vol. 48, No. 6, December, pp. 1309-1332. Crossref, https://doi.org/10.1016/j.euroecorev.2003.10.003

Newey, Whitney K., and Kenneth D. West, 1987, "A simple, positive semi-definite, heteroskedasticity and autocorrelation consistent covariance matrix," Econometrica, Vol. 55, No. 3, May, pp. 703-708.

Crossref, https://doi.org/10.2307/1913610

Rydzewski, Leo G., William G. Deming, and Philip L. Rones, 1993, "Seasonal employment falls over past three decades," Monthly Labor Review, Vol. 116, No. 7, July, pp. 3-14.

Veracierto, Marcelo, 2005, “Seasonal monetary policy," Economic Perspectives, Federal Reserve Bank of Chicago, Vol. 29, Third Quarter, pp. 49-68, available online, https://www.chicagofed.org/publications/ economic-perspectives/2005/3qtr2005-part4-veracierto.

Wright, Jonathan H., 2013, "Unseasonal seasonals?," Brookings Papers on Economic Activity, Vol. 44, No. 2, Fall, pp. 65-110. Crossref, https://doi.org/10.1353/eca.2013.0017

Menelik Geremew is the Stephen B. Monroe Assistant Professor of Money and Banking in the Department of Economics and Business at Kalamazoo College. François Gourio is a senior economist and research advisor in the Economic Research Department at the Federal Reserve Bank of Chicago. The authors would like to thank participants in a seminar at the Federal Reserve Bank of Chicago, especially Robert Barsky, Jeff Campbell, Spencer Krane, Alejandro Justiniano, and Marcelo Veracierto, for their comments and suggestions.

\section{(C) 2018 Federal Reserve Bank of Chicago}

Economic Perspectives is published by the Economic Research Department of the Federal Reserve Bank of Chicago. The views expressed are the authors' and do not necessarily reflect the views of the Federal Reserve Bank of Chicago or the Federal Reserve System.

Charles L. Evans, President; Daniel G. Sullivan, Executive Vice President and Director of Research; Anna L. Paulson, Senior Vice President and Associate Director of Research; Spencer Krane, Senior Vice President and Senior Research
Advisor; Daniel Aaronson, Vice President, microeconomic policy research; Jonas D. M. Fisher, Vice President, macroeconomic policy research; Robert Cox, Vice President, markets team; Gene Amromin, Vice President, finance team; Leslie McGranahan, Vice President, regional research; Marcelo Veracierto, Senior Economist and Economics Editor; Helen Koshy and Han Y. Choi, Editors; Julia Baker, Production Editor; Sheila A. Mangler, Editorial Assistant.

Economic Perspectives articles may be reproduced in whole or in part, provided the articles are not reproduced or distributed for commercial gain and provided the source is appropriately credited. Prior written permission must be obtained for any other reproduction, distribution, republication, or creation of derivative works of Economic Perspectives articles. To request permission, please contact Helen Koshy, senior editor, at 312-322-5830 or email Helen.Koshy@chi.frb.org.

ISSN 0164-0682 